\title{
The Biology of Northern Shrimp (Pandalus borealis) on the Flemish Cap
}

\author{
U. Skúladóttir, Gunnar Pétursson and Stefan H. Brynjólfsson \\ Marine Research Institute, Skúlagata 4, P.O. Box 1390, 121 Reykjavík, Iceland \\ Skúladóttir, U., G. Pétursson, and S. H. Brynjólfsson. 2007. The Biology of Northern Shrimp (Panda- \\ lus borealis) on the Flemish Cap. J. Northw. Atl. Fish. Sci., 37: 147-164. doi:10.2960/J.v37.m571
}

\begin{abstract}
This study reports on various biological features in the life history of northern shrimp (Pandalus borealis) on Flemish Cap. Northern shrimp on Flemish Cap are males for approximately their first three years. Then usually half change sex at age four years, and the rest at age five years, to become females from then on. Small shrimp are generally found at lesser depth than the larger ones so the size of shrimp increases with depth, especially that of males. Larger females seem to move to shallower waters in March when hatching starts. The size at sex change $\left(L_{50}\right)$ and the maximum length $\left(L_{\max }\right)$ are studied within and between seasons. Both $L_{50}$ and $L_{\max }$ have decreased in recent years. $L_{50}$ was 22.5 $\mathrm{mm} \mathrm{CL}$ on average in the seasons 1996/1997-2003/2004, but has decreased from $23.2 \mathrm{~mm}$ CL in $1997 / 1998$ to $22.4 \mathrm{~mm}$ CL in 2003/2004 (Icelandic commercial data) and from $24.3 \mathrm{~mm}$ CL in 1994 to $20.9 \mathrm{~mm}$ CL in 2003 (EU survey data). Also $L_{\max }$ has decreased from $29.8 \mathrm{~mm} \mathrm{CL}$ in 1996/1997 to $28.0 \mathrm{~mm} \mathrm{CL}$ in 2003/2004 (Icelandic commercial data). In spite of this, there is an invariant relationship between $L_{50}$ and $L_{\max }$, where $L_{50}$ is about $80 \%$ of the average $L_{\max }$ of northern shrimp on Flemish cap. This supports the theory of Charnov and Skúladóttir (2000) on the invariant relationship between $L_{50}$ and $L_{\max }$ in sex changing organisms. The same is found in Icelandic offshore waters and the Denmark Strait. The decline in $L_{50}$ could be related to the observed increase in temperature at 150 $\mathrm{m}$ in the last decade from $2.6^{\circ} \mathrm{C}$ in the years $1992-1996$ to $3.5^{\circ} \mathrm{C}$ in $1997-2003$. The sudden decline in the female biomass of shrimp on Flemish Cap between 1992 and 1994 appears to coincide with a drop in the age at sex change $\left(A_{50}\right)$ by one year in 1995 and 1996. Moreover, the increase in biomass of shrimp follows the disappearance of cod in the mid-1990s. As female shrimp biomass increased there was a delay in changing sex, showing the versatility of shrimp on Flemish Cap in adjusting to changes in sex-ratio. Growth of shrimp was fast in the earlier years and slower in later years indicating that food may be a limiting factor. The growth during the earlier years is faster than that of northern shrimp in the Barents Sea. Compared to other areas in the 1980s, the growth is slightly faster than that of the warm inshore waters of Iceland, but much slower than the growth of shrimp in the inshore waters of Sweden. The ovigerous period is studied for the first time on Flemish Cap and is estimated to be about eight months.
\end{abstract}

Key words: growth, maximum length, ovigerous periods, Pandalus borealis, sequential hermaphrodite, size at sex change.

\section{Introduction}

Northern shrimp (Pandalus borealis) is the main cold water species of shrimp in the world. The world catch has increased tremendously in the past decades from about 200000 metric tons (t) in 1983 to about $455000 \mathrm{t}$ in 2004 (FAO, 2000, 2006). The biology of northern shrimp has been studied for many years (see e.g. Berkley, 1930; Rasmussen, 1953; Horsted and Smidt, 1956; Allen, 1959; Haynes and Wigley, 1969; Shumway et al., 1985; Bergström, 1992a, 2000), but little has been published on the biology of northern shrimp on the Flemish Cap.
The occurrence of northern shrimp on Flemish Cap was known well before the fishery started owing to the 1988 demersal EU-Spain survey (Vázques, MS 1989). In 1991 and 1992 the Spanish investigators noticed that the shrimp biomass index had increased tremendously (Sainza, MS 1993) and in 1993 Canadians started their Flemish Cap shrimp fishery. A few commercial shrimp samples were obtained in the early years, mainly by Canada.

Parsons et al. (1998) were the first to make a comprehensive study of shrimp on Flemish Cap in relation to hydrography and dispersion around the Cap. They 
showed that northern shrimp was distributed all around Flemish Cap except for the south-east slope, at the depth of 250-550 m (Escalante et al., MS 1990; Mena, MS 1991; Parsons et al., 1998).

This study conducts various biological analyses on the international database that has been compiled for northern shrimp on Flemish Cap, including studying mean length by depth, calculations of the size at which $50 \%$ of shrimp change sex $\left(L_{50}\right)$, and growth. In studies of $L_{50}$ for Denmark Strait and adjoining Icelandic waters (Skúladóttir, 1998) and later for all Icelandic waters, $L_{50}$ in each population was found to be a fixed proportion, about $80 \%$ of maximum length $\left(L_{\max }\right)$ (Skúladóttir and Pétursson, 1999; Charnov and Skúladóttir, 2000). Charnov and Skúladóttir (2000) later put forward a theory that other marine species changing sex would do so at an invariant proportion of $L_{\max }$. The relationship between $L_{50}$ and $L_{\max }$ for shrimp on Flemish Cap will also be examined in this study. $L_{50}$ is also calculated for the overall frequency distributions from both the Faroese and the EU-Spain surveys. The egg-bearing periods of $P$. borealis on Flemish Cap are examined for the first time in this paper.

\section{Methods}

\section{Data Collection}

The geographic location of the Flemish Cap is shown in Fig. 1. For comparison of shrimp growth rates, other areas in the north Atlantic Ocean are also shown. The commercial Icelandic sampling scheme for Flemish Cap shrimp was introduced in 1996. In this scheme on the $1^{\text {st }}$ and $2^{\text {nd }}$ day, one sample was taken at noon and one sample in the evening. On the $3^{\text {rd }}$ day, a sample was taken in the morning (the night haul) and at noon. The scheme was repeated on the $4^{\text {th }}$ day. Thus one in six hauls were night samples. Icelandic observers sampled Flemish Cap shrimp onboard all Icelandic vessels in the same manner in the years 1996 through 2004.

The carapace length (CL) was measured on fresh shrimp to the nearest $0.5 \mathrm{~mm}$ from the eye socket to the mid-dorsal posterior edge of the carapace using Vernier calipers. Observers arranged the specimen on a table with length classes in a row. Each length class was sorted into males and females using the method of Rasmussen (1953) and the females were further sorted into primiparous and multiparous groups using the sternal spine criterion of McCrary (1971). Also females carrying headroes, eggs without eyes, and eggs with eyes, were distinguished. Finally observers had to look for shrimp that were both green in head and carried eyed eggs. No distinction was made between immature and mature males. No primary females (individuals that do not change sex but are females from hatching) were found by the observers in shrimp samples from Icelandic waters in 1962-1975. Therefore, it was agreed to start sorting shrimp into the aforementioned sex categories from the largest length class and working down to the smallest length class. If two successively smaller length classes contain only males (i.e. no females), then the rest of the smaller length classes were assumed to consist of only males.

The length-weight relationships were based on frozen samples collected in 1996. After thawing in air, each specimen was measured to the nearest $0.5 \mathrm{~mm}$, sexed and weighed to the nearest $0.1 \mathrm{~g}$. Later, the length-weight relationships were calculated for males and multiparous females separately.

For analysing the ovigerous periods, the proportion of females preparing to spawn was calculated by dividing the number of 'headroe' and egg-bearing individuals by the total number of female shrimp. A proportion was calculated for each day and then a weekly average calculated for summer and autumn samples to the end of October. From November onwards, the egg-bearing ratio was calculated from the proportion of egg-bearing females against all females without sternal spines. The primiparous females occurring at that part of the year were omitted as these were considered the new batch of females that had just changed sex from male to female and would be preparing spawning next summer (see Fig. 2 for the shrimp life history).

The size at sex change $\left(L_{50}\right)$ was calculated for each sample in a similar manner to Skúladóttir and Pétursson (1999), except that the proportion of all females (excluding transitionals) was the number of all females in each length-class divided by number of all stages, instead of just using the females without sternal spines. Fitting $L_{50}$ for the shrimp from the EU and Faroese survey samples was carried out on the combined length distribution of all samples in the survey. The sigmoid logistic curve (Pearl and Reed, 1920) fitted by minimizing the negative of a binomial likelihood was used for determining $L_{50}$ and $A_{50}$.

\section{Age assessment}

Two methods were used for ageing: deviation analysis and modal analysis.

The deviation analysis (Sund, 1930; Skúladóttir, 1981) was applied to the length-frequency distributions (LFD) of several months. The LFDs of all samples within 


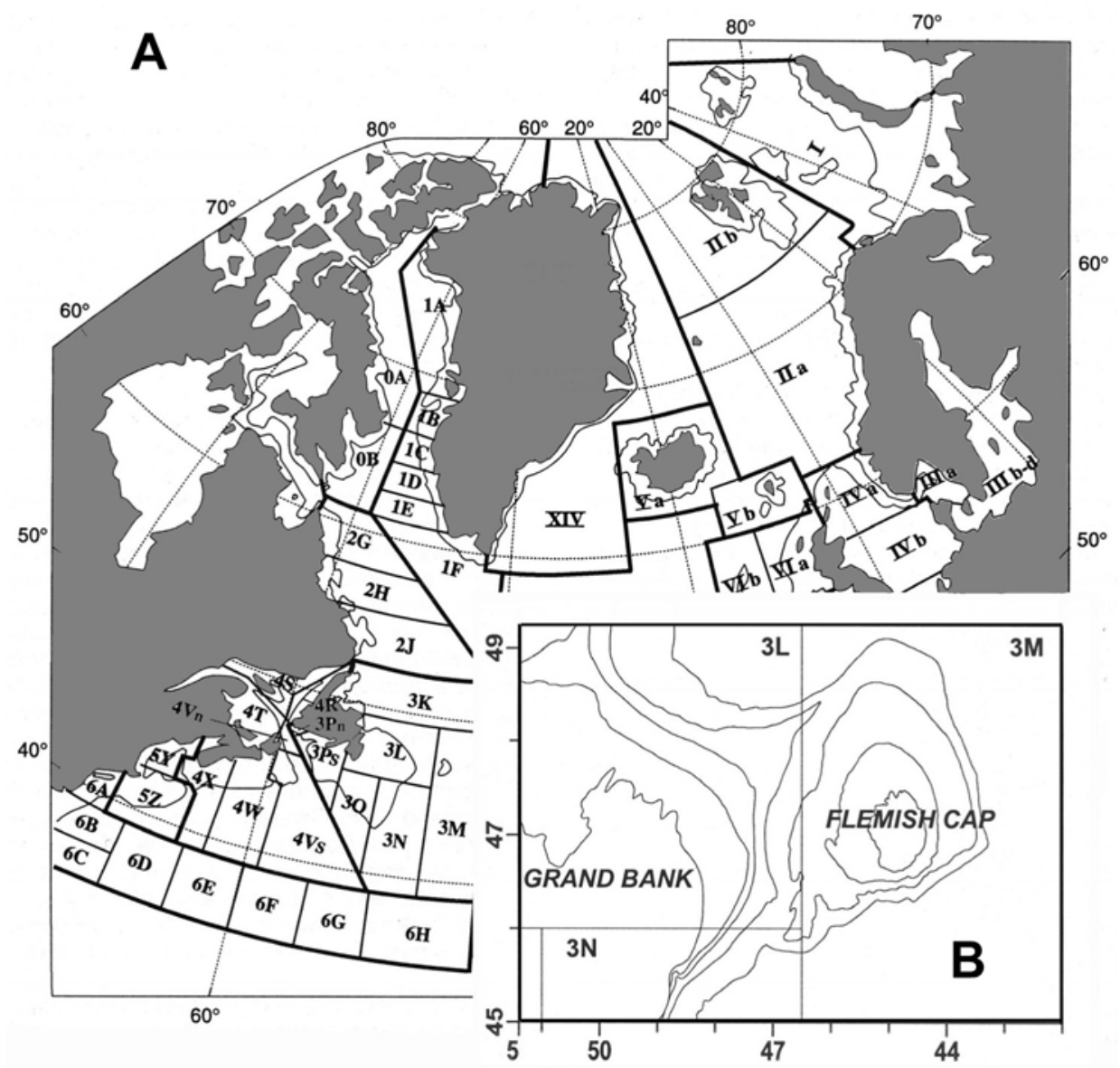

Fig. 1. (A) Map of the north Atlantic Ocean showing statisical areas defined by NAFO (west of $42^{\circ} \mathrm{W}$ ) and ICES (east of $42^{\circ} \mathrm{W}$ ). Adapted from Halliday and Pinhorn (1996). (B) The main study area of Flemish Cap (NAFO subdivision 3M) and part of the Grand Bank (NAFO subdivision 3L). Bathymetric contour lines are at 100, 300, 1000 and $2000 \mathrm{~m}$.

a month were combined and turned into a promille distribution. Then for example all the LFDs of June of the years 1993-2003 were summed to calculate an overall promille LFD for June. Then the LFD of June in each year was subtracted from the overall LFD of June for all years. The same was done for most months of the year as carried out by Skúladóttir (MS 2004). From this positive anomalies could be detected as indicators of a year-class stronger than average. These year-classes could then be followed for some years. The length at age was then estimated visually.

In the modal analysis (MacDonald and Pitcher, 1979), shrimp were separated into three categories, namely males, primiparous females (including transitionals) and multiparous females according to the sternal spine criterion (McCrary, 1971), The modal analysis was conducted on samples, combined within a month, in the three aforementioned categories. The lengths at age deduced from the deviation analysis were used as inputs. Moreover the number of age classes assumed from the deviation analysis was used as a guide. This analysis provided the mean lengths and proportions at age and sex each month, as well as standard deviations of proportions and mean lengths. The mean lengths were converted to mean weights using length-weight relationships for the appropriate months to calculate the number caught (Skúladóttir, MS 1997). An average length-at-age, weighted by number caught each month by nation, was calculated for the whole period.

\section{Results}

\section{Life history and year class strength}

The life history of Pandalus borealis on Flemish Cap is shown in Fig. 2 (Skúladóttir and Sigurjónsson, 2004). All individuals are assumed to start life as males as there were no small females found in the smallest length 


\section{Females with "headroes"}

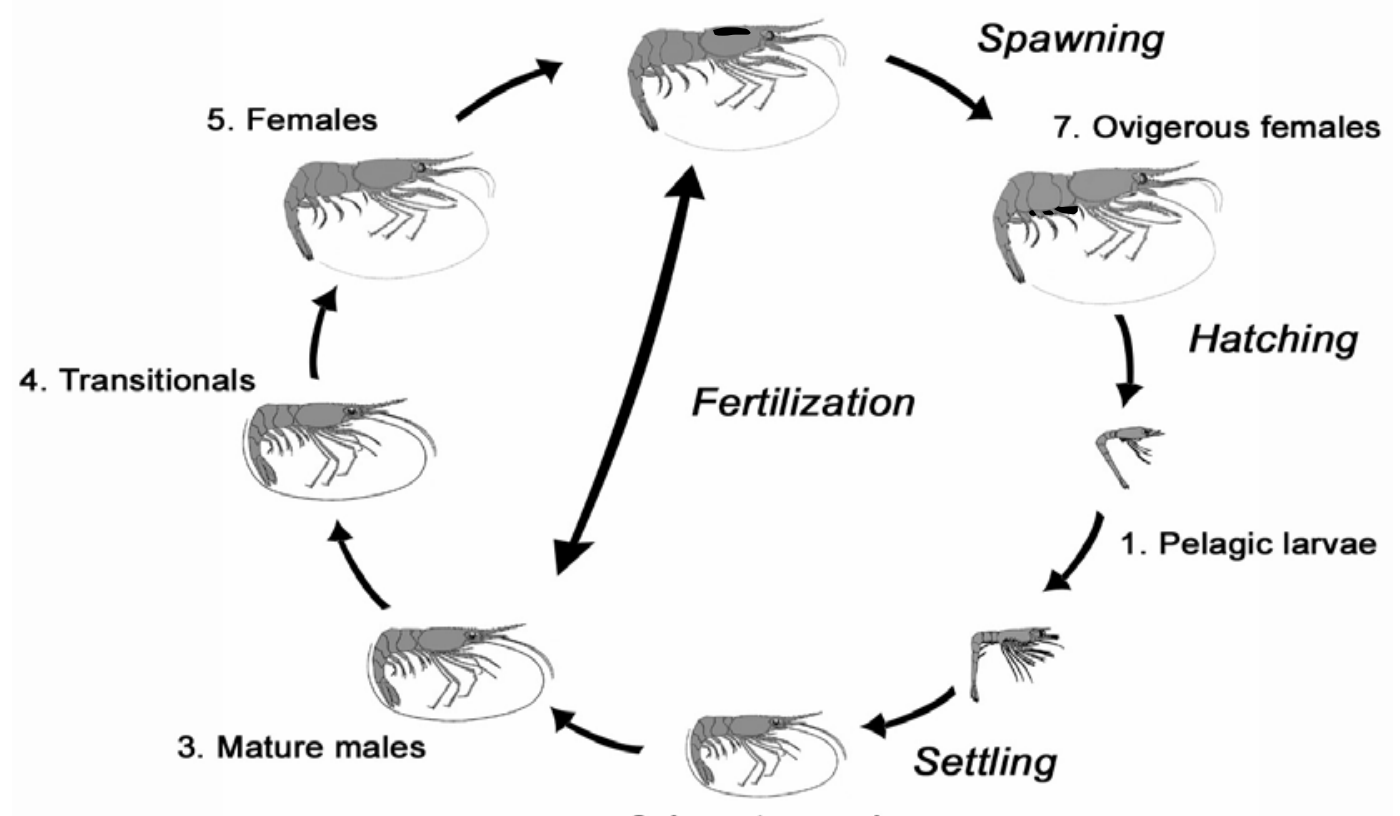

2. Immature males

Fig. 2. Life history of Pandalus borealis on Flemish Cap. Reproduced with permission from Skúladóttir and Sigurjónsson (2004).

groups analysed. So the so-called primary females that have been found, e.g. in Gullmarsfjord Sweden (Bergström, 1992a), were not found on Flemish Cap. At the age of four to five years, males change sex to females and breed for the rest of their life as females. The whereabouts of the shrimp less than one year old is unknown. One year olds are occasionally caught in small numbers by ordinary shrimp trawls ( $40 \mathrm{~mm}$ mesh size). More one year olds are caught by the juvenile bag $(6 \mathrm{~mm}$ mesh size) attached on the upper side near the rear end of the cod-end to the survey shrimp gear (Nicolajsen and Brynjólfsson, MS, 2003; Casas et al., MS 2004). Only small shrimp, one to three year olds are caught in the juvenile bag. The abundance of two year olds (Fig. 3) has been found useful as an index of recruitment, especially in the Faroese survey which was carried out from 1998 through 2003 using a $6 \mathrm{~mm}$ mesh juvenile bag (Nicolajsen and Brynjólfsson, MS 2003). The 1997 and 1999 year-classes seen as two year olds in 1999 and 2001 in Fig. 3 were quite strong and were also found to be strong in the years to follow later on in the fishery. The 2002 year-class, that first showed up as strong one year olds in Fig. 3, was also very prominent in the fishery in 2004 and 2005 (Skúladóttir and Pétursson, MS 2005).

\section{Length-weight relationships}

It is necessary to account for the monthly variation in the weight of multiparous shrimp when calculating, for example, catch in numbers. The data were collected in 1996 and some of the length-weight relationships have been previously published (Skúladóttir, MS 1997). The results for males were combined in all available months (Table 1). Moreover it is assumed that females with sternal spines have the same length-weight relationship as males, as these are not egg-bearing. Multiparous females (females without sternal spines) are sometimes egg-bearing and are then much heavier than other multiparous females not bearing eggs. In some months all multiparous females are ovigerous as egg-bearing is almost $100 \%$. In other months, a proportion is not egg-bearing (see below). The length-weight relationships for multiparous females is variable even when spawning is complete (Table 1). As the number of multiparous females investigated are rather few each month, it is advisable to use a longer period for the mean weight at length of multiparous females when spawning is complete, namely that of September through March. In other months, at times of hatching and spawning, the individual months like April for partly hatched and July and August for partly spawned multiparous females should be used. However when shrimp are fully hatched, like in May-June, these two months may be combined for multiparous females (Table 1).

\section{Temperature}

There has been some change in temperature through the years as shown in Table 2. The data are average temperatures taken at the depth of $150 \mathrm{~m}$ along the 

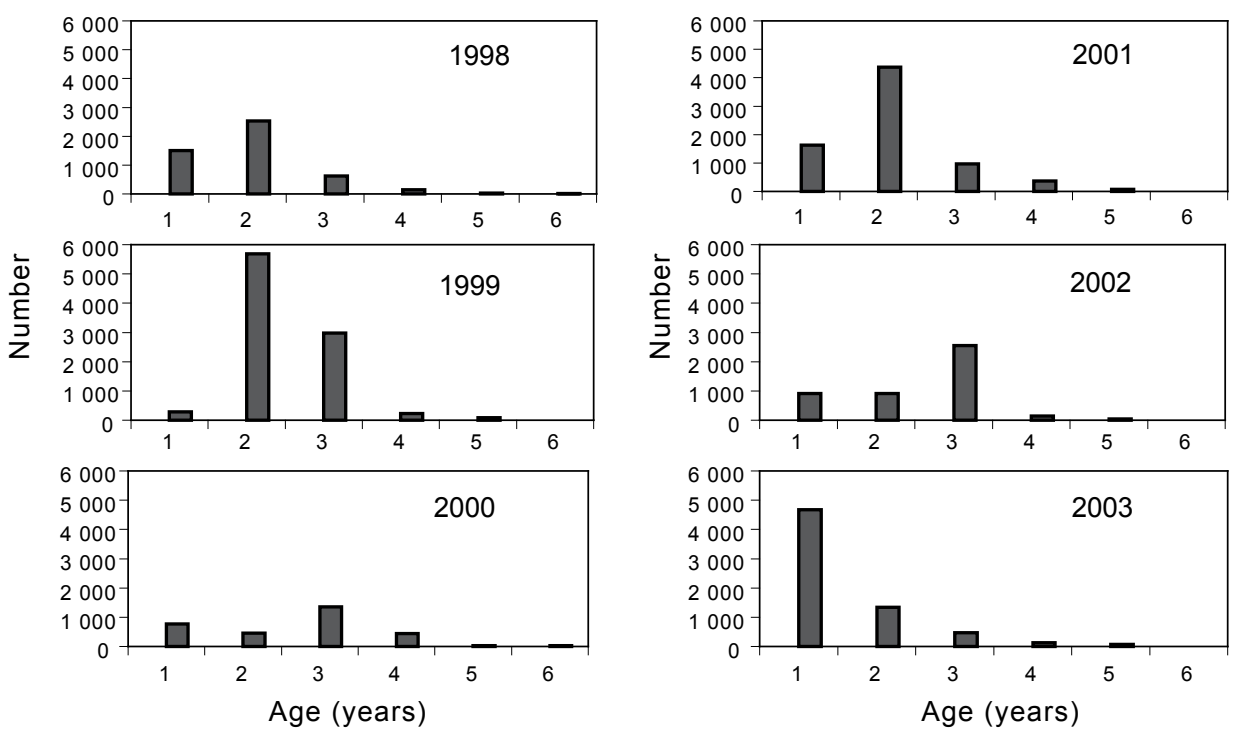

Fig. 3. Age distribution (numbers) of shrimp in the juvenile bag in the Faroe Islands surveys on Flemish Cap in 1998-2003.

TABLE 1. Length-weight relationships for male and multiparous female Pandalus borealis in 1996, where $y$ is the weight $(\mathrm{g})$ and $x$ is the carapace length $(\mathrm{CL}, \mathrm{mm})$.

\begin{tabular}{|c|c|c|c|c|c|c|c|}
\hline \multirow[b]{2}{*}{ Period } & \multirow[b]{2}{*}{ No. of specimens } & \multicolumn{2}{|c|}{ In $y=a \ln x-b$} & \multirow[b]{2}{*}{$r^{2}$} & \multicolumn{3}{|c|}{ Weight $(\mathrm{g})$ at } \\
\hline & & $a$ & $\bar{b}$ & & $\overline{\mathrm{CL}} 20 \mathrm{~mm}$ & CL $23 \mathrm{~mm}$ & CL $26 \mathrm{~mm}$ \\
\hline \multicolumn{8}{|l|}{ Males } \\
\hline March-December & 953 & 3.037 & 7.549 & 0.939 & 4.71 & 7.20 & 10.44 \\
\hline \multicolumn{8}{|l|}{ Multiparous females } \\
\hline March & 51 & 3.258 & 8.166 & 0.860 & 4.92 & 7.76 & 11.58 \\
\hline April & 74 & 2.676 & 6.368 & 0.913 & 5.20 & 7.56 & 10.49 \\
\hline April-June & 127 & 2.778 & 6.689 & 0.919 & 5.12 & 7.55 & 10.61 \\
\hline May-June ${ }^{1}$ & 53 & 2.676 & 6.368 & 0.931 & 5.20 & 7.56 & 10.49 \\
\hline July & 122 & 2.921 & 7.144 & 0.941 & 4.99 & 7.50 & 10.73 \\
\hline August & 66 & 3.111 & 7.689 & 0.897 & 5.11 & 7.89 & 11.55 \\
\hline September & 97 & 2.753 & 6.565 & 0.921 & 5.38 & 7.90 & 11.07 \\
\hline October & 114 & 3.050 & 7.458 & 0.899 & 5.36 & 8.21 & 11.93 \\
\hline November & 147 & 2.636 & 6.083 & 0.846 & 6.13 & 8.87 & 12.25 \\
\hline December & 133 & 2.812 & 6.745 & 0.863 & 5.36 & 7.94 & 11.21 \\
\hline September-December ${ }^{2}$ & 491 & 2.899 & 6.989 & 0.864 & 5.45 & 8.17 & 11.66 \\
\hline September-March & 542 & 2.929 & 7.085 & 0.863 & 5.42 & 8.16 & 11.68 \\
\hline
\end{tabular}

${ }^{1}$ Females have no eggs on the pleopods; ${ }^{2}$ All females carry eggs on their pleopods.

Flemish Cap transect (Colbourne, personal communication). In 1992 the value was $2.85^{\circ} \mathrm{C}$, decreasing to a minimum in 1994 of $1.7^{\circ} \mathrm{C}$. From then on there was a warming up of waters to $4.3^{\circ} \mathrm{C}$ in 1999 and decreasing again to $3.15^{\circ} \mathrm{C}$ in 2001 .

\section{Breeding cycle}

The breeding cycle has been studied for a number of years (seasons). In the first year, 1996, only hatching was deduced, being half finished around 4 April of the year
(Fig. 4, Table 3). Spawning and hatching was followed closely over five seasons (Fig. 4, Table 3). However in one season, 1996/97, hatching could not be followed because of lack of sampling in the critical weeks during March and April. Also, the 2000/2001 season lacks data around hatching although it should be noted that hatching had not begun by 1 April and resembles thus the seasons of 1997/98, 2001/2002 and 2002/2003 where the first hatching starts late compared to other seasons. Spawning starts on the average about the 15 July. About 
TABLE 2. Biological data of Pandalus borealis at Flemish Cap that are used in this paper for comparison. The mean $L_{50}$ and $L_{\max }$ values from the Icelandic commercial data included the months June-December and May the following Year. Both $L_{50}$ and $L_{\max }$ are from individual samples for the Icelandic data whereas the $L_{50}$ from the EU-Spain and the Faroese survey data are calculated from a combined length frequency distribution for the whole survey each year. Temperature is from Colbourne (personal communication).

\begin{tabular}{|c|c|c|c|c|c|c|c|c|}
\hline \multirow{2}{*}{ Year } & \multirow{2}{*}{$\begin{array}{c}\text { International } \\
\text { data } \\
A_{50}\end{array}$} & \multicolumn{3}{|c|}{ Icelandic data ${ }^{1}$} & \multirow{2}{*}{$\begin{array}{c}\text { EU survey } \\
\text { data } \\
L_{50}\end{array}$} & \multirow{2}{*}{$\begin{array}{c}\text { Faroese } \\
\text { survey data } \\
L_{50}\end{array}$} & \multirow{2}{*}{$\begin{array}{c}\text { Combined } \\
\text { Average } \\
\bar{L}_{50}\end{array}$} & \multirow{2}{*}{$\begin{array}{l}\text { Canadian data } \\
\text { Temperature at } \\
150 \mathrm{~m} \text { depth }{ }^{\circ} \mathrm{C}\end{array}$} \\
\hline & & $L_{50}$ & $L_{\max }$ & $L_{50} / L_{\max }$ & & & & \\
\hline 1992 & & & & & 23.18 & & 23.18 & 2.85 \\
\hline 1993 & 4.50 & & & & 23.40 & & 23.40 & 3.00 \\
\hline 1994 & 4.50 & & & & 24.29 & & 24.29 & 1.70 \\
\hline 1995 & 3.50 & & & & 22.79 & & 22.79 & 2.94 \\
\hline 1996 & 3.37 & 22.85 & 29.78 & 0.767 & 22.77 & & 22.81 & 2.95 \\
\hline 1997 & 4.24 & 23.17 & 28.64 & 0.809 & 22.82 & 22.87 & 22.95 & 3.18 \\
\hline 1998 & 4.26 & 22.74 & 28.47 & 0.799 & 22.82 & 22.91 & 22.82 & 3.73 \\
\hline 1999 & 4.24 & 22.25 & 28.22 & 0.788 & 20.85 & 21.28 & 21.46 & 4.29 \\
\hline 2000 & 4.28 & 22.01 & 27.68 & 0.795 & 20.75 & 21.54 & 21.43 & 3.45 \\
\hline 2001 & 4.36 & 22.43 & 27.38 & 0.819 & 21.60 & 21.98 & 22.00 & 3.15 \\
\hline 2002 & 4.23 & 22.22 & 27.71 & 0.802 & 20.72 & 21.38 & 21.44 & 3.30 \\
\hline 2003 & 4.31 & 22.48 & 28.00 & 0.803 & 20.89 & & 21.69 & 3.74 \\
\hline Mean & 4.16 & 22.52 & 28.24 & 0.798 & 22.24 & 21.99 & 22.52 & 3.19 \\
\hline
\end{tabular}

${ }^{1}$ For Icelandic data these are seasons instead of whole years, denoted by the year representing most of the data.

$50 \%$ of females have spawned by 6 August. On average, all females have spawned on Flemish Cap by 24 August, and thus unlike some far north populations females on Flemish Cap spawn every year. The eggs are then carried on the pleopods during the autumn and winter. The hatching starts on the average on 19 March, by 2 April $50 \%$ have hatched their eggs, and hatching is usually completed by 15 April.

Assuming that the length of the egg-bearing is from 6 August (the date when $50 \%$ have spawned) to 2 April (the date when $50 \%$ have hatched their eggs), the eggbearing period is about eight months (Table 3). The length of the ovigerous period is almost the same in all seasons + /- half a week, except in the year 1999 (season 1998/1999) when the period was shortest and the temperature higher than usual (Table 2).

\section{Mean size of sex groups by depth}

The smaller males are more prevalent at shallow waters as judged by mean size by depth (Fig. 5A and B). The example shown is that of year 2000 from the Icelandic fishery. However the same general picture is observed in all the years 1996 through 2003.

Females are also bigger as depth increases, although the regression coefficient is lower than that of mean size of males by depth e.g. in the year 2000 (Fig. 5C). However, plotting the mean size of females by depth per month revealed an interesting feature, namely that there was often a low regression coefficient in linear relationships fitted for April at the time of hatching. The slope was also very low in March (in 3 out of 7 years), in April (in 5 out of 7 years) and in May (in 3 out of 8 years). The lack of slope could be related to large females moving to shallower waters at time of hatching. Fig. 5D is an example of this, showing hardly any difference in size of females by depth in the March-April period in year 2000. Males did not show any seasonal differences in size on depth (Fig. 5A and B).

\section{Size and age at sex transition}

After being male for some years the shrimp change sex to become females. Average $L_{50}$ and average $L_{\max }$ each month are taken from Skúladóttir et al. (MS 2004). Recalculating $L_{50}$ for northern Icelandic waters in the years 1988-1996 (Skúladóttir and Pétursson, 1999), using the same method as is used here, lowers the result of average $L_{50}$ for northern shrimp in offshore Icelandic waters from $23.65 \mathrm{~mm} \mathrm{CL}$ to $23.00 \mathrm{~mm} \mathrm{CL}$, namely a decrease of $0.65 \mathrm{~mm}$. However $L_{50}$ is variable on Flemish Cap within the year. $L_{50}$ increases slightly from the beginning of June to reach a high level in November through January. After that there is a drop in the monthly average $L_{50}$ in February, March and April (Fig. 6A). This is due to a new batch of females entering the fishery. The average difference is as much as $2 \mathrm{~mm}$ within the year (1996-2004). Thus if an average $L_{50}$ is calculated 


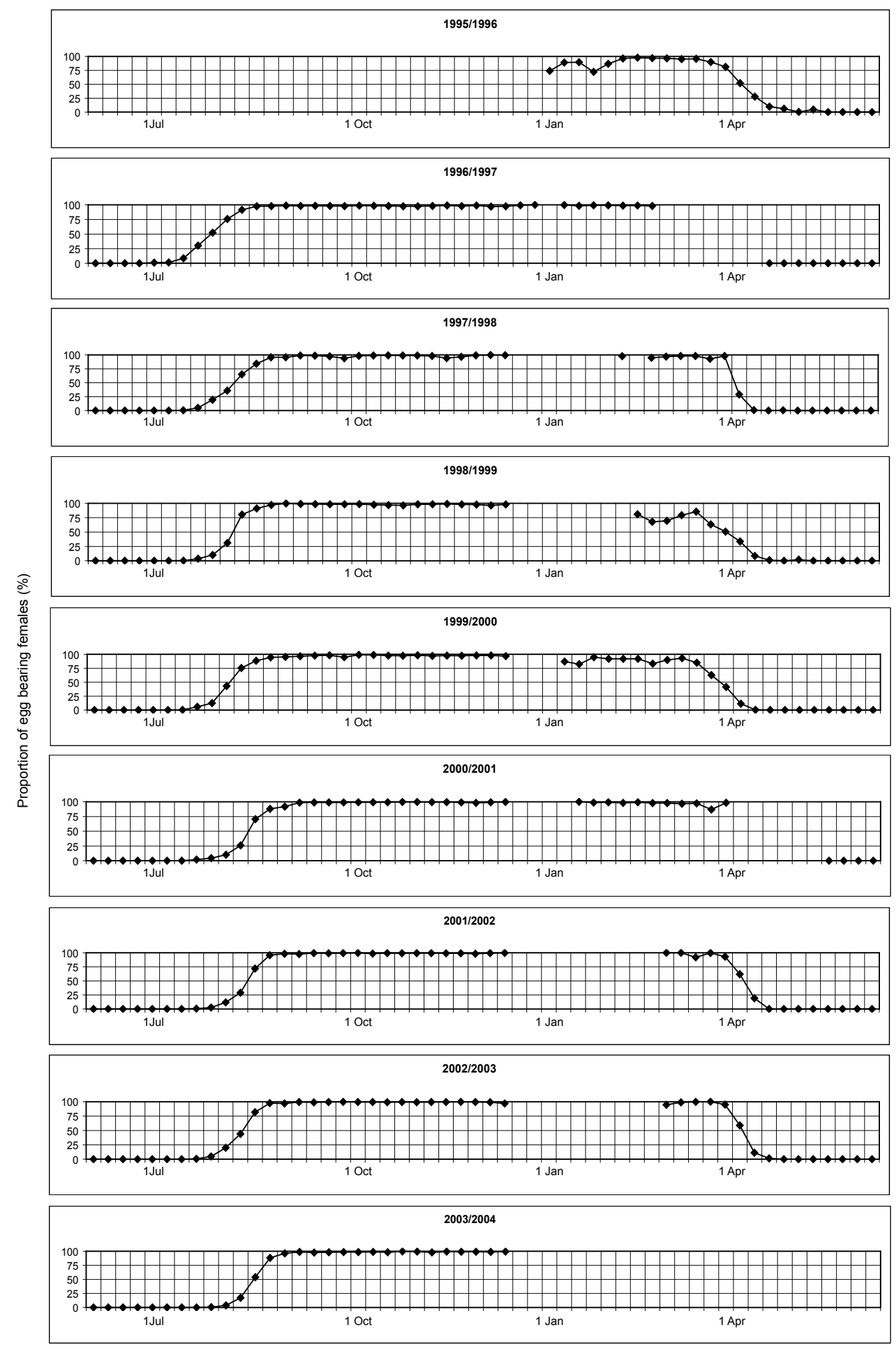

Time of year

Fig. 4. Percentage of egg-bearing female Pandalus borealis from 1995/1996 to 2003/2004. 
TABLE 3. The date when certain stages are reached in the egg-bearing periods, as estimated from Figure 4. Length of the ovigerous period is estimated from time when $50 \%$ of female shrimp have spawned to the time when $50 \%$ have hatched their eggs.

\begin{tabular}{|c|c|c|c|c|c|c|c|}
\hline Year & $\begin{array}{l}\text { Start of } \\
\text { spawning }\end{array}$ & $\begin{array}{l}50 \% \text { of } \\
\text { females } \\
\text { spawned }\end{array}$ & $\begin{array}{c}\text { All females } \\
\text { spawned }\end{array}$ & $\begin{array}{l}\text { First } \\
\text { females } \\
\text { hatched }\end{array}$ & $\begin{array}{l}50 \% \text { of } \\
\text { females } \\
\text { hatched }\end{array}$ & $\begin{array}{l}\text { End of } \\
\text { hatching } \\
\text { time }\end{array}$ & $\begin{array}{c}\text { Length of } \\
\text { egg-bearing } \\
\text { period (weeks) }\end{array}$ \\
\hline $1995 / 1996$ & & & & $21 \mathrm{Mar}$ & $4 \mathrm{Apr}$ & 2 May & \\
\hline 1996/1997 & $4 \mathrm{Jul}$ & $25 \mathrm{Jul}$ & 15 Aug & & & $18 \mathrm{Apr}$ & \\
\hline $1997 / 1998$ & $11 \mathrm{Jul}$ & 5 Aug & 22 Aug & $31 \mathrm{Mar}$ & $4 \mathrm{Apr}$ & $11 \mathrm{Apr}$ & 33.5 \\
\hline $1998 / 1999$ & $11 \mathrm{Jul}$ & $1 \mathrm{Jul}$ & $22 \mathrm{Aug}$ & 14 Feb & $4 \mathrm{Apr}$ & $28 \mathrm{Mar}$ & 32.0 \\
\hline $1999 / 2000$ & $11 \mathrm{Jul}$ & $1 \mathrm{Jul}$ & $22 \mathrm{Aug}$ & $14 \mathrm{Mar}$ & $24 \mathrm{Mar}$ & $11 \mathrm{Apr}$ & 33.5 \\
\hline $2000 / 2001$ & $18 \mathrm{Jul}$ & 12 Aug & 5 Sep & & & & \\
\hline $2001 / 2002$ & $25 \mathrm{Jul}$ & 12 Aug & $22 \mathrm{Aug}$ & $31 \mathrm{Mar}$ & $4 \mathrm{Apr}$ & $18 \mathrm{Apr}$ & 32.5 \\
\hline $2002 / 2003$ & $18 \mathrm{Jul}$ & 8 Aug & $22 \mathrm{Aug}$ & $31 \mathrm{Mar}$ & $4 \mathrm{Apr}$ & $18 \mathrm{Apr}$ & 33.0 \\
\hline $2003 / 2004$ & $25 \mathrm{Jul}$ & 15 Aug & 29 Aug & & & & \\
\hline Mean & $15 \mathrm{Jul}$ & $6 \mathrm{Aug}$ & 24 Aug & $19 \mathrm{Mar}$ & $2 \mathrm{Apr}$ & $15 \mathrm{Apr}$ & 32.9 \\
\hline
\end{tabular}
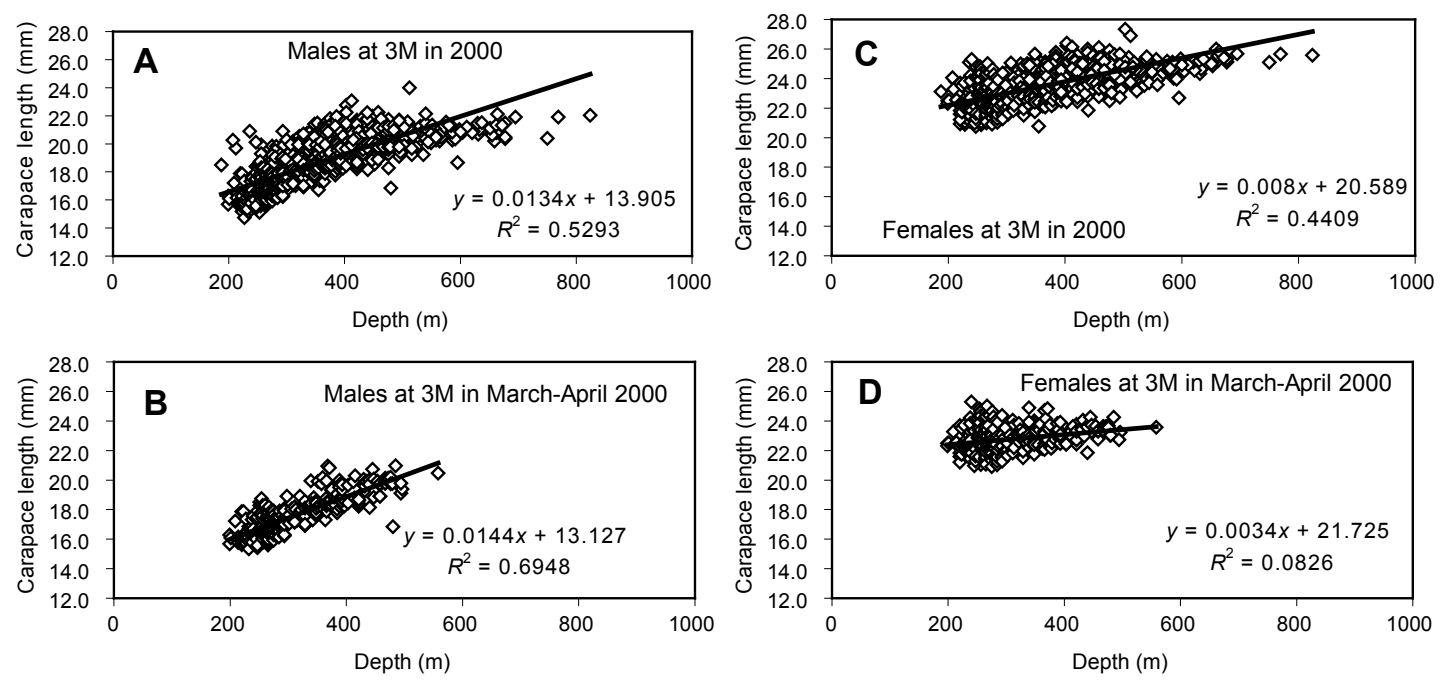

Fig. 5. Mean length of male and female Pandalus borealis by depth in year 2000 on Flemish Cap. (A) and (C) are fitted for the whole year, and (B) and (D) show the difference in size-related depth-distribution of males and females at the time of hatching in March through April.

per year it is wise to exclude the months between February and April (Fig.6A) as is done in Table 2 and Fig. 7A. January is excluded, as often samples are missing in January. There is a slight variation in the mean maximum length $\left(L_{\max }\right)$ each month within the year but no trend was evident (Fig. 6B). Fig. 7 and Table 2 show the $L_{50}$ and $L_{\max }$ by seasons. Apparently there is little change in $L_{50}$ per season from 1996/97 to $2003 / 2004$ in the Icelandic commercial data. However there was a change in mesh size in the commercial fishery increasing from 40 to $44 \mathrm{~mm}$ (open mesh) in the last years. So a change in selection, could result in a slight overestimate of $L_{50}$ in these data. Table 2 also shows the values of $L_{50}$ of shrimp calculated for the whole EU survey each year.
Data are taken from various Spanish investigators (Del Rio and Sainza, MS 1997; Del Rio, MS 1998; Garabana, MS 1999; Bruno, MS 2000; Diaz, MS 2001; Del Rio et al., MS 2002; MS 2003). The EU-Spain data before 1992 were not used as the classification into primiparous and multiparous females was inaccurate. The EU-Spain survey data show a trend going from $24.3 \mathrm{~mm}$ in 1994 to $20.8 \mathrm{~mm}$ in 2000 . Since $2000, L_{50}$ has fluctuated without a trend. The $L_{50}$ values calculated from the Faroese survey data (Nicolajsen, MS 1998, MS 1999, MS 2000, MS 2001, MS 2002, MS 2003) show the same trend as the EU-Spain data, namely a decrease in $L_{50}$ from $22.9 \mathrm{~mm}$ in 1998 to 21.3 in 1999 staying rather stable after that (Table 2). The overall mean $L_{50}$ for shrimp on Flemish 

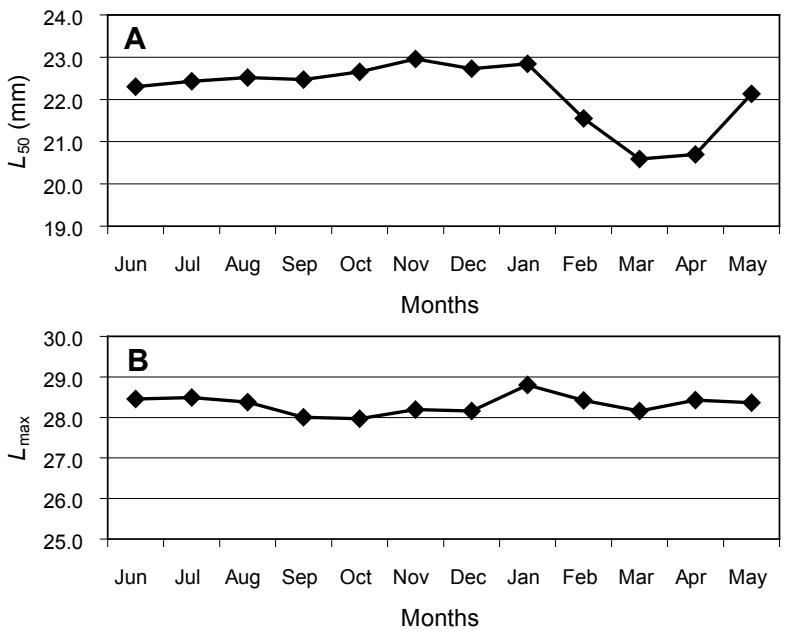

Fig.6. (A) the $L_{50}$ and (B) the $L_{\max }$ of Pandalus borealis by months. Data points are the means of eight seasons from 1995/1996 to 2003/2004. (Icelandic commercial data).
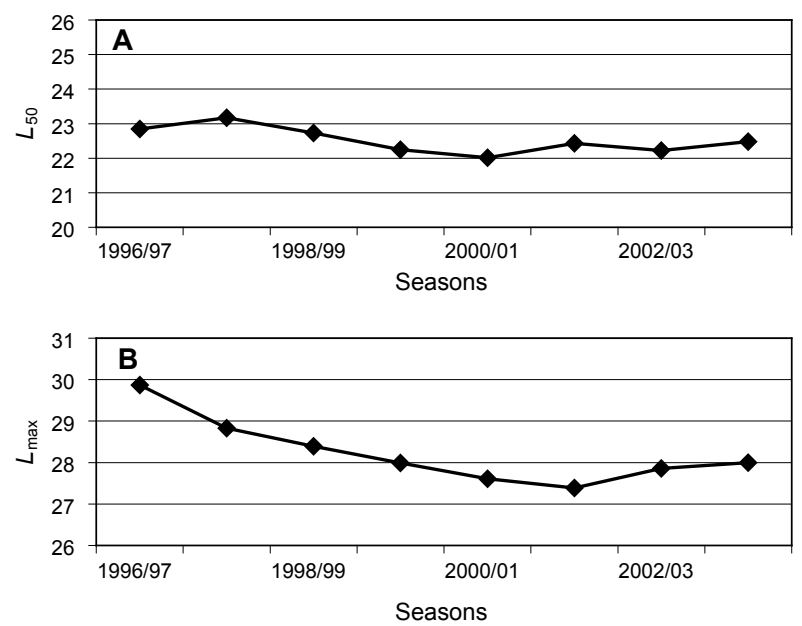

Fig. 7. Annual changes in Pandalus borealis (A) $L_{50}$ (January to April are omitted, see text), and (B) $L_{\max }$. (Icelandic commercial data).

Cap for the six seasons $1997 / 1998$ to $2002 / 2003$, is 22.5 $\mathrm{mm}$ for Icelandic data, $21.6 \mathrm{~mm}$ in the EU-Spain data and $22 \mathrm{~mm}$ for the Faroese data (Table 2). There could be a small difference in the method of measuring between the Faroese and EU-Spain investigators or the method of sex determination. As one can not decide which is the most correct result, an average $L_{50}$ from the three sources, Icelandic, EU-Spain and Faroese data was calculated and used in Figures 8-9.

The mean $L_{\max }$ in the Icelandic data decreased with years, being highest in the season 1996/97 at $29.8 \mathrm{~mm}$, decreasing to $27.4 \mathrm{~mm}$ in the season 2001/2002 (Table 2)

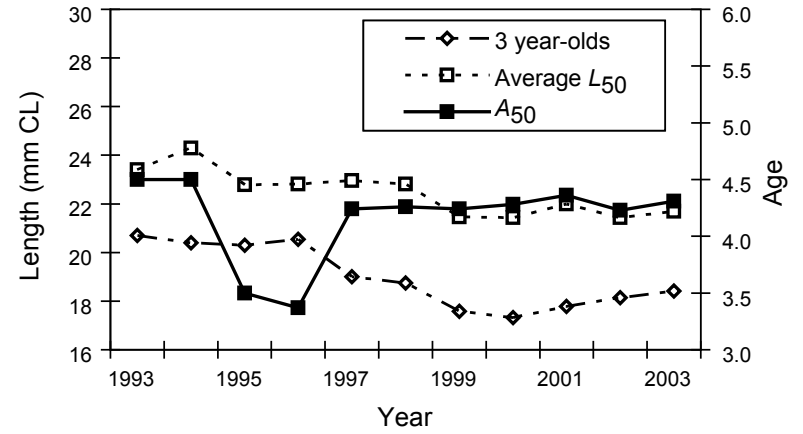

Fig. 8. Average $L_{50}$ from Iceland, EU-Spain and Faroe Islands surveys, and mean length of 3 year olds and $A_{50}$ from international commercial database for Pandalus borealis.
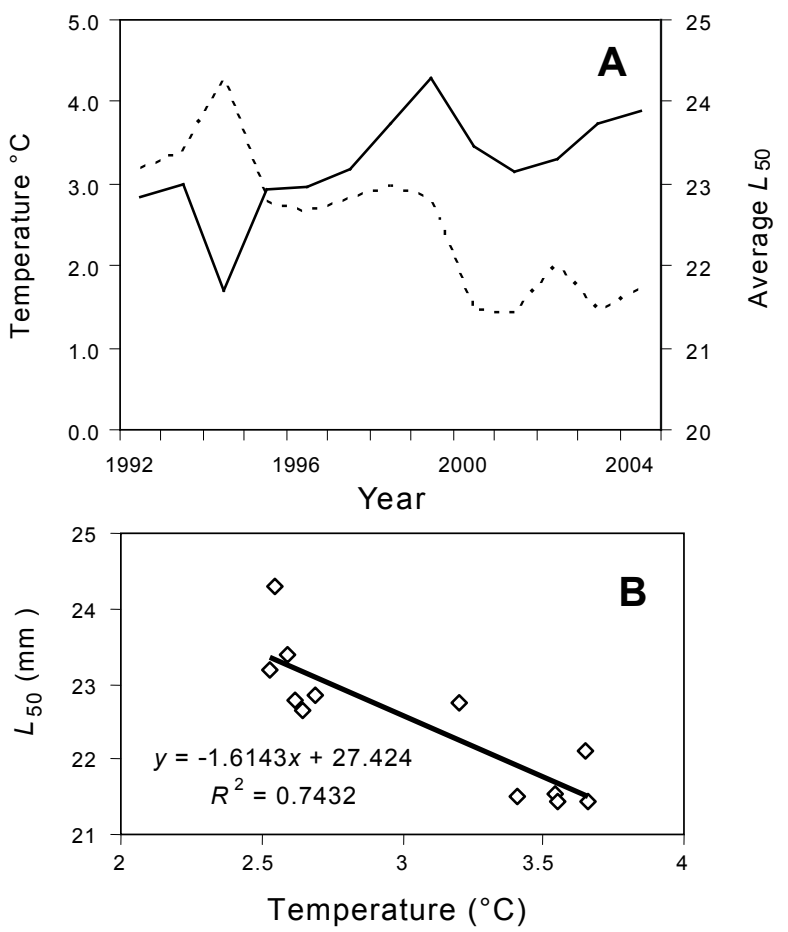

Fig. 9. (A) Temperature ${ }^{\circ} \mathrm{C}$ at $150 \mathrm{~m}$ depth (solid line) and an average $L_{50}$ of Pandalus borealis (dotted line), and (B) regression statistics of data in $\mathbf{A}$ where temperature is a moving four-year average.

and increasing again to $28 \mathrm{~mm}$ in 2003 (Table 2, Fig. 7B). The proportion $L_{50} / L_{\max }$ (from Icelandic commercial data) varies from $77 \%$ to $82 \%$ being $80 \%$ on average for the Flemish Cap (Table 2).

Age at sex change based on age determination in Skúladóttir (MS 2003b) is given in Table 4. The proportions for each year are calculated from the proportions of females in each age-class. Following the year classes 
TABLE 4. Maturity of females (transitionals, primiparous and multiparous) at age, based on the period January to September. From Parsons (MS 1996) and the international database (Skúladóttir and Petursson, 2005).

\begin{tabular}{cccccccccccc}
\hline \hline Years & 1993 & 1994 & 1995 & 1996 & 1997 & 1998 & 1999 & 2000 & 2001 & 2002 & 2003 \\
\hline 1 & 0.000 & 0.000 & 0.000 & 0.000 & 0.000 & 0.000 & 0.000 & 0.000 & 0.000 & 0.000 & 0.000 \\
2 & 0.000 & 0.000 & 0.000 & 0.000 & 0.000 & 0.000 & 0.000 & 0.000 & 0.000 & 0.000 & 0.000 \\
3 & 0.000 & 0.000 & 0.000 & 0.060 & 0.013 & 0.000 & 0.000 & 0.000 & 0.000 & 0.000 & 0.000 \\
4 & 0.000 & 0.000 & 1.000 & 1.000 & 0.514 & 0.431 & 0.300 & 0.356 & 0.120 & 0.608 & 0.258 \\
5 & 1.000 & 1.000 & 1.000 & 1.000 & 1.000 & 1.000 & 1.000 & 1.000 & 1.000 & 1.000 & 1.000 \\
6 & 1.000 & 1.000 & 1.000 & 1.000 & 1.000 & 1.000 & 1.000 & 1.000 & 1.000 & 1.000 & 1.000 \\
7 & 1.000 & 1.000 & 1.000 & 1.000 & 1.000 & 1.000 & 1.000 & 1.000 & 1.000 & 1.000 & 1.000 \\
\hline
\end{tabular}

diagonally in the table it appears that the 1990 year-class changes sex at age 5, the 1991 and 1992 year-classes changed sex at age 4 . After this a proportion of shrimp (12-61\%) appeared to spawn as females when 4 years old and the rest as 5 year old. The age when $50 \%$ of shrimp spawn as females $\left(A_{50}\right)$ is calculated from Table 4 and listed in Table 2.

Fig. 8 shows a downward trend in the size of $L_{50}$ going from 24.3 in 1994 to 21.4 in year 2000 remaining at the same level to 2003. A decrease in the size at 3 years is also shown (Fig. 8). To complicate this there is a drop in $A_{50}$ from 4.5 to 3.5 years between 1994 and 1995, followed by an increase in the years 1997-2003. Figs. 9 and 10 show various factors that may affect the size/age at sex change. Fig. 9A shows the decrease in $L_{50}$ by years as temperature at $150 \mathrm{~m}$ depth increases. The relationship between 4-year moving averages of temperature and $L_{50}$ is highly significant (Fig. 9B). Figs. 8 and 10A show the drop in $A_{50}$ in 1995 following a drastic decrease of female biomass from EU-Spain survey (Casas et al., MS 2004) from 1992 to 1994. The relationship with a one-year timelag being significant at $\mathrm{P}<0.05$ (Fig. 10B). There was however no relationship between temperature (4-year moving average) and $A_{50}$.

\section{Growth}

The length deviations for Flemish Cap shrimp can be followed in Skúladóttir (MS 2003a) while the mean lengths at age as estimated from the deviations are given in Skúladóttir et al. (MS 2004). There the year-classes 1993-1997 and 1999 were followed. The 1998 yearclass was considered small and therefore not traceable.

The lengths-at-age from the deviation analysis method were then used as inputs for modal analysis. The results of mean length at age by year-classes from modal analysis are shown in Table 5. The von Bertalanffy growth (VBG) curve was then fitted to the six year-classes of 1993-1999 both as estimated by deviation analysis and by modal analysis (Table 6). There are some differ-
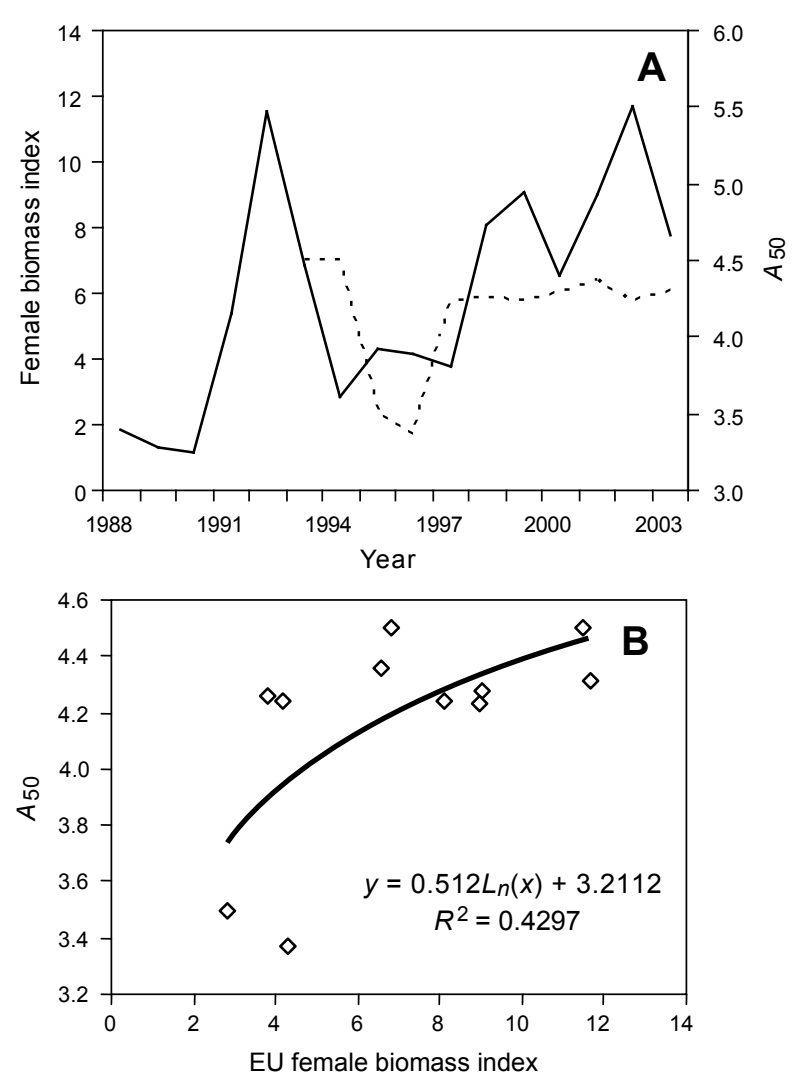

Fig. 10. (A) Pandalus borealis female biomass indices from EU surveys (solid line) and $A_{50}$ from commercial data (dotted line), and (B) regression statistics for data in A where $A_{50}$ is lagged by one year.

ences in $K$ and $L_{\infty}$, growth being slightly slower applying the modal analysis as compared to the deviation analysis method resulting in a lower value of $K$ and a higher value of $L_{\infty}$. Then the year-classes were grouped together into faster growing and slower growing year-classes (Table 6, Fig. 11) showing the growth of the 1990-1993 yearclasses on one hand and the 1994-1999 year-classes on the other. The value of $K$ was very high for the fast growing year-classes, at 0.34 , but only 0.16 for the 
TABLE 5. Carapace length (mm) of shrimp at age as assessed by Modal analysis (Mix) for the period January through September. The first three year-classes are mainly estimated by Parsons and Veitch (1997) and the rest is estimated by Skúladóttir (MS 2003a).

\begin{tabular}{|c|c|c|c|c|c|c|c|c|c|c|}
\hline $\begin{array}{l}\text { Age } \\
\text { (Year-class) }\end{array}$ & ) 1990 & 1991 & 1992 & 1993 & 1994 & 1995 & 1996 & 1997 & 1998 & 1999 \\
\hline 1 & & & 10.40 & & & & 10.44 & & & \\
\hline 2 & & 16.80 & 16.40 & 15.00 & 15.25 & 15.73 & 14.90 & 14.49 & 13.18 & 15.23 \\
\hline 3 & 20.70 & 20.40 & 20.30 & 20.54 & 19.01 & 18.75 & 17.58 & 17.32 & 17.78 & 18.14 \\
\hline 4 & 22.90 & 22.20 & 24.70 & 23.32 & 22.09 & 21.34 & 20.46 & 20.84 & 21.06 & 20.81 \\
\hline 5 & 25.30 & 24.80 & 25.56 & 25.29 & 24.20 & 24.27 & 23.56 & 23.76 & 24.28 & \\
\hline 6 & 26.60 & 28.33 & 26.47 & 26.42 & 26.08 & 25.13 & 25.69 & 26.01 & & \\
\hline $7^{1}$ & 29.28 & 29.07 & 29.57 & 29.32 & 26.93 & 28.25 & 29.36 & & & \\
\hline
\end{tabular}

${ }^{1}$ The lengths for age 7 are poorly estimated and not used in fitting the VBG.

TABLE 6. The growth constants from the VBG fitted for several year-classes of Pandalus borealis on Flemish Cap (NAFO subdivision 3M). For comparison the growth constants for the 1990-1993 year-classes shrimp from Hopen Deep, Barents Sea (ICES area I), inshore areas like Isafjardardjup in West Iceland (ICES area Va) and Gullmarsfjord Sweden (ICES area III) are shown.

\begin{tabular}{llcccc}
\hline \hline Location & \multicolumn{1}{c}{ Method } & Years & $L_{\infty}$ & $K$ & $t_{o}$ \\
\hline Flemish Cap & Deviation analysis & $1993-1999$ & 32.50 & 0.2653 & 0.22 \\
Flemish Cap & Modal analysis & $1993-1999$ & 35.83 & 0.1916 & -0.37 \\
Flemish Cap & Modal analysis & $1990-1993$ & 30.51 & 0.3424 & 0.21 \\
Flemish Cap & Modal analysis & $1994-1999$ & 38.73 & 0.1579 & -0.60 \\
Barents Sea & Modal analysis & $1990-1993^{1}$ & 37.57 & 0.1436 & -0.14 \\
Iceland & Modal analysis & $1981-1989^{2}$ & 28.50 & 0.2800 & -0.40 \\
Sweden & Modal analysis & $1980-1985^{3}$ & 27.90 & 0.6000 & 0.25 \\
\hline
\end{tabular}

${ }^{1}$ Based on Aschan (2000), ${ }^{2}$ Based on Skúladóttir et al. MS 1989, ${ }^{3}$ Bergström, (1992b, 2000)

slow growing year-classes (Table 6). Fig. 12 shows the growth curve of Flemish Cap shrimp (the fast growing year-classes) as compared to the shrimp in other parts of the world, namely those of Barents Sea (ICES area I) (Aschan, 2000), Isafjardardjup, Iceland,, (ICES area Va) (Skúladóttir et al., MS 1989), and Gullmarsfjord, Sweden (ICES area IIIa) (Bergström, 1992b, 2000). Shrimp in Gullmarsfjord shows the fastest growth where bottom temperature is around $5^{\circ} \mathrm{C}$ (Bergström, 2000). Flemish Cap shrimp also shows fast growth with temperature about $3.2^{\circ} \mathrm{C}$ compared to Isafjardardjup where bottom temperature is about $4.5^{\circ} \mathrm{C}$ (Skúladóttir and Pétursson, 1999). The Barents Sea shrimp shows the slowest growth and the coldest temperatures at $1-2^{\circ} \mathrm{C}$ (Bergström, 2000). The growth constants of those populations are shown in Table 6. Age assessments of the 1994-1999 year classes from various sources (Skúladóttir and Diaz, MS 2001; Casas et al., MS 2004; Nicolajsen MS 1999, MS 2000, MS 2001, MS 2002, MS 2003) using modal analyses give similar results (Table 7).

\section{Biomass of shrimp}

Biomass of northern shrimp on Flemish Cap has been measured in two surveys, namely the EU-Spain survey (Del Rio et al., MS 2003; Casas et al., MS 2004) and the Faroe Islands survey (Nicolajsen, MS 2003) (see Table 8 and Fig. 13). As there was a major change in the calculation of the biomass index of the EU survey in 2003 (Del Rio et al., MS 2003), as compared to the previous surveys, only the series from 1988 to 2002 is presented here with the addition of one value for 2003 transformed by the Warren method (Casas et al., MS 2004). For both surveys the female portion of the biomass is used as an indicator of stock size (NAFO, 2005). The results of the Faroese shrimp biomass survey are similar to the EU-Spain survey in the same years if looked upon as an index. Fig. 10A shows the EU-Spain female biomass along with $A_{50}$. The EU-Spain female biomass shows an increase in the years 1998 through 2003 as compared to the years prior to 1998 with the exception of the years 1992 and 1993 (Table 8). The drop in biomass of females 


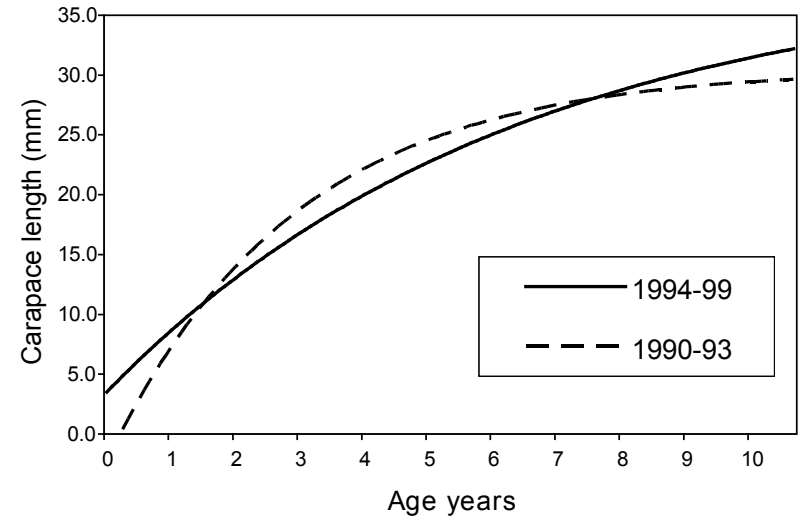

Fig. 11. Pandalus borealis von Bertalanffy Growth curves on Flemish Cap for the faster growing 1990-1993 and the slower growing 1994-1999 year-classes.

TABLE 7. Mean carapace length ( $\mathrm{mm}$ ) of Pandalus borealis of the 1994-1999 year-classes on Flemish Cap, calculated from VBG, and mean length-at-age of the same year-classes from the EU-Spain and the Faroe Islands survey data.

\begin{tabular}{lccc}
\hline $\begin{array}{l}\text { Age } \\
\text { years }\end{array}$ & $\begin{array}{c}\text { Icelandic } \\
\text { data } \\
\mathrm{mm}\end{array}$ & $\begin{array}{c}\mathrm{EU} \\
\text { data } \\
\mathrm{mm}\end{array}$ & $\begin{array}{c}\text { Faroese } \\
\text { data } \\
\mathrm{mm}\end{array}$ \\
\hline 1.5 & 10.9 & & 10.1 \\
2.5 & 15.0 & 15.2 & 15.1 \\
3.5 & 18.5 & 18.6 & 18.1 \\
4.5 & 21.4 & 21.3 & 20.8 \\
5.5 & 23.9 & 23.8 & 23.0 \\
6.5 & 26.1 & 26.1 & 25.0 \\
\hline
\end{tabular}

from 1992 to 1994 has been related to the drastic change in age at sex change of shrimp in 1995 described above (Table 2, Fig. 10B).

As biomass of shrimp has increased substantially in the last decade, as measured in the EU surveys, it was considered that perhaps there was a connection between the collapse of the cod stock and the increase in shrimp biomass. Fig. 13 shows how the biomass index of cod decreased after 1994 on Flemish Cap in the EU surveys (Saborido-Ray and Vázques, MS 2003). By 1998, the biomass index of shrimp, as measured in the EU survey, increased considerably and has remained high ever since (Del Rio et al., MS 2003; Casas et al., MS 2004).

\section{Discussion}

The simplest rule for a protandric sex-changer is that the organisms all begin life as males and after a couple of years breeding as males change to females and from

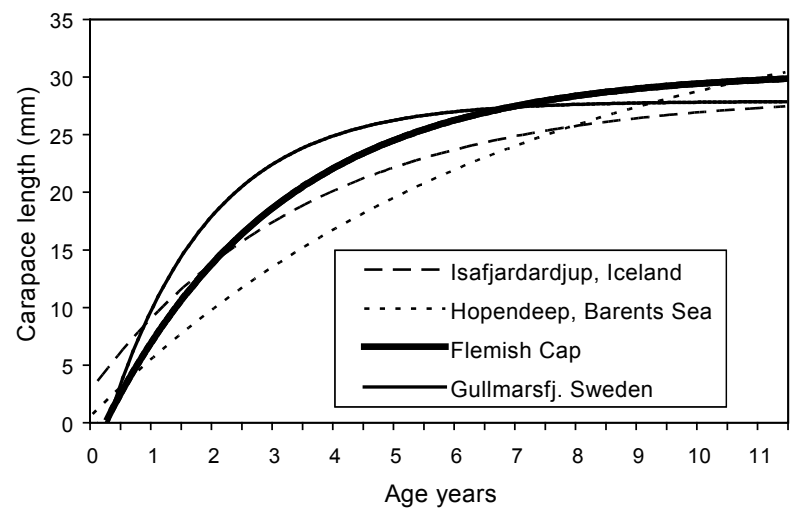

Fig. 12. Pandalus borealis von Bertalanffy Growth (VBG) curves on Flemish Cap, 1990-1993 year-classes as compared to the same year-classes of northern shrimp in Barents Sea. For comparison there are also VBG curves for the 1980s year-classes of northern shrimp in fjords of Sweden and Iceland.

then on spend their life as females. This is what is shown here in Fig. 2. Charnov (1982) studied the "evolutionary stable strategy rule" (ESS) of Parker (1982) for the species Pandalus borealis and maintained that although most northern shrimp are males at the beginning of life and when mature, these spawn as males, a small proportion is female from the beginning. Those starting life as males spend $1-3$ years in the male phase and then change sex to become females. Thus Charnov and Bergström (1987) talk about two alternate life histories in northern shrimp and maintain that most Pandalus borealis populations have two alternative life histories, with the bulk of the year-class behaves according to the simple rule mentioned above, but a proportion of a year-class starts life as females, termed primary females and these breed only as females. These are not found on Flemish Cap, or in Icelandic waters (where all specimens of the shrimp samples were scrutinized in the years 1960-1975). We propose that primary females are only found in the southern-most populations of the Atlantic Ocean thus being an exception to the main rule. Charnov and Bergström (1987) also talk about what they call the second most common form of alternate life-history where the second breeders show a mixture of males and females. This is often seen in the Flemish Cap population, namely half of the year-class changing sex in one year, perhaps after breeding 2-3 years as a male. In the next year, the rest of the year-class changes sex and breeds from then on as females.

The ovigerous period of Flemish Cap shrimp, is about 8 months on average from late July to late March, different from northern shrimp in areas shown by Shumway et al. (1985). The bottom temperature is 


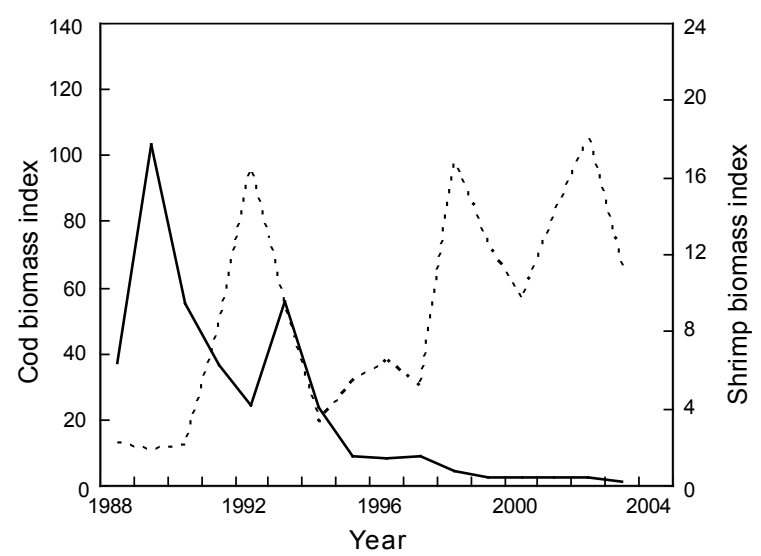

Fig. 13. EU survey cod biomass (solid line) and total shrimp biomass indices (dashed line) in the years 1988-2003 on Flemish Cap.

3.5- $4^{\circ} \mathrm{C}$ on Flemish Cap so egg-bearing would be expected to be similar to the 6 months for shrimp found at Mist fjord (Norway) where the temperature is $4^{\circ} \mathrm{C}$, spawning in November and hatching in May. However the egg-bearing period on Flemish Cap, indicates ovigerous shrimp inhabit temperatures less than $4^{\circ} \mathrm{C}$. The eggbearing period is some nine months at Jan Mayen and the bottom temperature there is $1^{\circ} \mathrm{C}$ (Shumway et al., 1985). Also in some Icelandic offshore areas the egg-bearing period is around 10 months at $0^{\circ} \mathrm{C}$, but the females only spawn every second year (Skúladóttir et al., 1991). In the Icelandic northern offshore area spawning is in mid-July and hatching in mid May. Egg-bearing is almost 100\% annually in northern shrimp on Flemish Cap indicating the female shrimp spawn every year.

Several authors have noted the prevalence of smaller males at shallower depth on Flemish Cap and females at greater depths (Escalante et al., MS 1990; Kristjánsson, MS 1996; Del Rio and Sainza, MS 1997; Nicolajsen, MS 2002, MS 2003; Del Rio et al., MS 2002, MS 2003). Age has been assessed by depth throughout the year (Skúladóttir and Nicolajsen, MS 2002). In the three years studied there, one year olds (only found in year 2000) were $33 \%$ more prevalent in shallow waters ( $<250 \mathrm{~m}$ depth) compared to all depths and two year olds were $18 \%$ more frequent in shallow waters as compared to all depths in all three years.

The same authors as mentioned above (Escalante et al., MS 1990; Kristjánsson, MS 1996; Del Rio and Sainza, MS 1997; Nicolajsen, MS 2002, MS 2003; Del Rio et al., MS 2002, MS 2003) also found mean size of females to increase with depth. Plotting the mean size of males and females per sample respectively for the years
TABLE 8. Biomass indices $(\mathrm{t})$ for Pandalus borealis estimated from EU-Spain and Faroe Islands surveys on Flemish Cap.

\begin{tabular}{|c|c|c|c|c|}
\hline \multirow[b]{2}{*}{ Year } & \multicolumn{2}{|c|}{ EU-Spain } & \multicolumn{2}{|c|}{ Faroe Islands } \\
\hline & $\begin{array}{c}\text { Total } \\
\text { biomass }\end{array}$ & $\begin{array}{l}\text { Female } \\
\text { biomass }\end{array}$ & $\begin{array}{c}\text { Total } \\
\text { biomass }\end{array}$ & $\begin{array}{l}\text { Female } \\
\text { biomass }\end{array}$ \\
\hline 1988 & 2164 & 1874 & & \\
\hline 1989 & 1923 & 1340 & & \\
\hline 1990 & 2139 & 1132 & & \\
\hline 1991 & 8211 & 5362 & & \\
\hline 1992 & 16531 & 11509 & & \\
\hline 1993 & 9256 & 6839 & & \\
\hline 1994 & 3337 & 2823 & & \\
\hline 1995 & 5413 & 4286 & & \\
\hline 1996 & 6502 & 4149 & & \\
\hline 1997 & 5096 & 3807 & 16370 & 6731 \\
\hline 1998 & 16844 & 8091 & 22804 & 12559 \\
\hline 1999 & 12430 & 9051 & 16477 & 8863 \\
\hline 2000 & 9720 & 6553 & 20380 & 10154 \\
\hline 2001 & 14106 & 8977 & 19036 & 9374 \\
\hline 2002 & 18109 & 11664 & 27634 & 11761 \\
\hline $2003^{1}$ & 11197 & 7756 & 27246 & 12402 \\
\hline
\end{tabular}

${ }^{1}$ Index transformed by Warren method (Casas et al., MS 2004)

1996 through 2003 shows the same trend for the whole year combined, with bigger shrimp at greater depth. On the other hand fitting regressions to the mean size of females on depth per month was in some years almost without slope in the months March to April and sometimes also in May as indicated by the very low regression coefficients. Here only the year 2000 is shown as an example (Fig. 5). The migration of ovigerous females to shallower waters when hatching their eggs seems a likely explanation.

Temperature may affect $L_{50}$, and so it must be considered when comparing the size at sex change on Flemish Cap with other areas. Although the temperature at $300-400 \mathrm{~m}$ depth on Flemish Cap is between $3.5^{\circ} \mathrm{C}$ and $4^{\circ} \mathrm{C}$ (Parsons et al., 1998; Cabanas, MS 2003; Colbourne, MS 2003; Gill et al., 2004), shrimp stay in the upper layers during the night. The average temperature of the years 1992-2003 at the depth of $150 \mathrm{~m}$ is somewhat colder at $3.2^{\circ} \mathrm{C}$ (Colbourne, personal communication). So the mean temperature that shrimp experience in is probably a bit colder than that of the bottom on Flemish Cap. When using the same criterion as in this paper, the $L_{50}$ for $P$. borealis in the Icelandic offshore (ICES area Va) was $23.6 \mathrm{~mm} \mathrm{CL}$ (in area 15 of Skúladóttir and Pétursson (1999)), very similar to the average $22.5 \mathrm{~mm}$ $\mathrm{CL}$ on Flemish Cap. This northernmost area in Icelandic 
waters has a bottom temperature of $0^{\circ} \mathrm{C}$. Nearer to the coast of Iceland where bottom temperature is $0.1-1.7^{\circ} \mathrm{C}$, average $L_{50}$ is $22.5-23.4 \mathrm{~mm} \mathrm{CL}$, the same as that of the Flemish Cap. In the inshore area Isafjardardjup of Iceland, $L_{50}$ was only $18.5 \mathrm{~mm} \mathrm{CL}$ where bottom temperature was $4.5^{\circ} \mathrm{C}$ on average and as high as $27.3 \mathrm{~mm} \mathrm{CL}$ in Denmark Strait (Skúladóttir and Pétursson, 1999). The average $L_{50}$ of inshore Icelandic waters was $18.9 \mathrm{~mm} \mathrm{CL}$. Hansen and Aschan (2000) found an $L_{50}$ of approximately 22.5 and $23.7 \mathrm{~mm}$ CL (adjusted to the same criterion as used in this paper) at bottom temperatures of $1.4^{\circ} \mathrm{C}$ and $0.8^{\circ} \mathrm{C}$ respectively, in the Svalbard area (ICES area IIb). This is very similar to what was found on Flemish Cap although the temperature was much lower at Svalbard. Wieland (2004), using the same method for defining $L_{50}$ as in this study, found the value of $L_{50}$ in West Greenland waters (NAFO Subarea 1) to be 23.4-24.4 $\mathrm{mm} \mathrm{CL}$ at bottom temperatures between $1.8-2.6^{\circ} \mathrm{C}$.

Temporal changes in $L_{50}$ have been studied by several authors. At West Greenland $L_{50}$ usually had no connection with density of females or density of all stages (Wieland, 2004). When there was a relationship it was negatively correlated, namely increased density of females caused a slight decrease in $L_{50}$. On Flemish Cap there was no relationship between average $L_{50}$ (from Icelandic, EU-Spain and Faroes) and EU survey biomass of females. There was however a relationship between temperature and $L_{50}$. According to Wieland (2004), at West Greenland there was a significant relationship between increase of temperature from $1-4^{\circ} \mathrm{C}$ accompanied by a prominent decrease in $L_{50}$ of some $2 \mathrm{~mm}$. This is in line with what happened on Flemish Cap although the increase in temperature was only from about $2.6^{\circ} \mathrm{C}$ to $3.6^{\circ} \mathrm{C}$ and the decrease in $L_{50}$ from $22.8-24.3 \mathrm{~mm}$ CL in 1992-1997 to $21.5 \mathrm{~mm}$ CL in years 1999-2003. However the drop in $A_{50}$ on Flemish Cap could not be explained by temperature alone, but instead a drastic change in female biomass. In a way this substantiates Charnov and Anderson's (1989) theory that size at sex change (and also age at sex change if growth rate was the same) would decrease as abundance of multiparous females would decrease. In this case there was only a slight decrease in $L_{50}$ although $A_{50}$ dropped by one year as the growth was faster in the years 1992-1996 than in the years 1997-2003.

Koeller et al. (2000) studied the size at sex change in northern shrimp using the mean size at transition $\left(L_{t}\right)$ (mean size of transitionals and primiparous females) in spring instead of $L_{50}$. Koeller et al. (2000) found that $L_{t}$ decreased with increasing abundance of multiparous females. This is contrary to the theory of Charnov and
Anderson (1989) and not apparent on Flemish Cap. On the Scotian Shelf (NAFO area $4 \mathrm{X}, 4 \mathrm{~W}$ ), $L_{t}$ increased as bottom temperature decreased in the years 1982-1988 and stayed high during the period 1995-2000 despite increasing temperatures (Koeller et al., 2003). This is also opposite to what was observed on Flemish Cap and West Greenland in the late 1990 s where $L_{50}$ decreased with increasing temperatures.

Maximum length has also gradually decreased with years, this might be expected as the stock is no longer a virgin stock (Fig. 6B). An average proportion of $L_{50} / L_{\max }$ for all years is however 0.80 compared to $0.79-0.81$ for two populations in ICES areas Va and XIV (Charnov and Skúladóttir, 2000). Charnov and Skúladóttir (2000) postulated that as a rule marine animals that change sex do so at an invariant proportion of the maximum length. The underlying assumption is that the values for age at maturity, times instantaneous adult mortality as well as $K$ (growth constant of VBG) divided by instantaneous adult mortality is invariant (Charnov 1993). The invariant rule of Charnov and Skúladóttir (2000) holds for northern shrimp on Flemish Cap as it does for shrimp in Icelandic waters and Denmark Strait. Allsop and West (2003a, b) carried out a large study on 77 species and populations of sex-changing organisms like, fish, crustaceans, echinoderms, molluscs and polycheate worms. Most of those were protogynous and a smaller part were protandrous hermaphrodites. They found out that the proportion $L_{50} / L_{\max }$ was also invariant but at lower proportion, namely 0.72 on average, thus supporting the theory of Charnov and Skúladóttir (2000). Allsop and West (2003a) recorded maximum size for each population, whereas Skúladóttir and Pétursson (1999) and in the present study, average maximum length was that of all samples of the population. Average $L_{\max }$ is much lower than the one highest value of CL per population and hence the proportion $L_{50} / L_{\max }$ becomes much higher in, for example, northern shrimp on Flemish Cap as compared to the results of Allshop and West (2003a, b).

Much thought has been given to maturation with respect to food availability and temperature in general. In a way, size at sex change can be caused by the same factor as triggers onset of maturity in species that do not change sex, namely the slowing down of growth. Pauly (1981, 1984) maintains that growth is limited by the interaction between oxygen consumption and metabolism. Therefore animals mature at a certain proportion of their maximum length in a given environment. Several authors have studied this and most fish appear to start producing offspring at a certain proportion of their average maximum length. Length at first maturity $\left(L_{m}\right)$ divided by $L_{\max }$ is on 
average 0.76 for 80 stocks of several species of pelagic fish, but only 0.4-0.5 in tunas (Beverton and Holt, 1959; Beverton, 1963; Mitani, 1970) and about 0.78 for 647 species (and stocks) studied by Pauly (2000). Pauly's $L_{m} / L_{\max }$ of 0.78 is strikingly similar to the average $L_{50} / L_{\max }$ of 0.80 found here for Flemish Cap shrimp.

The growth of shrimp is different between the two periods on Flemish Cap, namely the early 1990s, 1990-1993 year-classes and the late 1990s, 1994-1999 year-classes. One would expect growth to be faster in the later period on Flemish Cap as temperature increased by $1{ }^{\circ} \mathrm{C}$ at $150 \mathrm{~m}$ depth. Possibly this is caused by a higher density of shrimp as suggested by Kristjánsson (MS 2001). Growth relies heavily on correct age determination which is difficult for shrimp. By using the deviation method (Sund, 1930; Skúladóttir, 1981, MS 2004) we are of the opinion that the number of age-classes are estimated more correctly than by just using the modal analysis. Modal analysis appears to under- or over-estimate the number of year-classes.

Comparing the growth curve of the 1990-1993 year-classes of shrimp on Flemish Cap with the same year-classes in Barents Sea, shows that growth is much faster on Flemish Cap. The growth of shrimp in the 1980s in Gullmarsfjord, Sweden (ICES area IIIa, Fig 1) was the fastest of all as might be expected where bottom temperature is $5^{\circ} \mathrm{C}$. The growth of shrimp in Isafjardardjup, Iceland (ICES area Va western inshore) where bottom temperature is $4.5^{\circ} \mathrm{C}$ is rather similar to that of the Flemish Cap shrimp where temperature is about $3.2^{\circ} \mathrm{C}$ at $150 \mathrm{~m}$ depth and between 3.5 and $4^{\circ} \mathrm{C}$ at the bottom.

Atkinson and Sibly (1997) discuss factors affecting growth and ask the question why organisms are usually bigger in colder environments. They maintain that at a given temperature, growth rate increases with increases in food availability, then size at maturity increases as food increases. They also say that length at first maturity $L_{m}$ decreases as temperature increases although initial growth may be faster than usual. This is presumably caused by maturity being reached earlier in life. If changing sex is analogous with maturation of dioecious organisms where there is no sex change, then the same rule should apply on Flemish Cap. This is not so. The sudden drop in age at sex change in 1995 and 1996 appears to be triggered by some factor due to the decrease in female biomass and not increase in temperature. So it is possible that with increased density, growth rate decreased but that sex change occurred later as temperature increased by about $1{ }^{\circ} \mathrm{C}$ from the years 1994-1996 to $1998-2003$ on Flemish Cap. In the first years, 1993 and 1994, shrimp appeared to change sex very late compared to the whole series. Growth rate was fast and the density of females was high. $A_{50}$ was then 4.5 years and temperature was a little higher than later, namely about $3^{\circ} \mathrm{C}$. These changes in age at sex change are complicated and more research is needed to understand what is controlling this.

The biomass of shrimp has increased greatly on Flemish Cap since 1997 after the collapse of the cod (Fig. 13). Other authors have investigated the predatorprey relationship between cod and shrimp in several areas. This can be a very complicated factor as alternate prey, capelin for example, might play a part (Lilly et al., 2000). Berenboim et al. (1986) were the first to draw attention to the negative relationship between biomass of cod and northern shrimp in the Barents Sea and Svalbard areas (ICES I and IIb). Berenboim et al., (2000) follow this up for the years 1982-1998 in the same area. Stefánsson et al. (1998) found a highly significant negative relationship between cod abundance and shrimp recruitment as well as CPUE of shrimp in Icelandic offshore waters (ICES area Va). Lilly et al. (2000) are not so certain about the impact of cod on the shrimp stock on the northeast Newfoundland shelf (NAFO Div. 2J, 3K and $3 \mathrm{~L}$ ) for the early $1980 \mathrm{~s}$ whereas they consider the larger increase in shrimp biomass in the 1990s to be related in part to the collapse of the cod .

\section{Conclusions}

Life history of the sequential hermaphrodite Pandalus borealis on Flemish Cap appears to be rather complicated. First all shrimp are males changing sex to female at age 4 or 5 depending on various factors. During the female stage females spawn annually in late July, hatching their eggs in late March, the ovigerous periods being 8 months at bottom temperature of $3.5-4^{\circ} \mathrm{C}$. There are no studies of shrimp larvae on Flemish Cap. Small/young shrimp stay at lesser depth than bigger/older shrimp.

Length-weight relationships are presented and show that not only are females per length heavier when eggbearing than males but there are also differences in the weight of multiparous females between months depending on whether they are egg-bearing or not and also in the months when some females have hatched their eggs or some have started spawning and others have not.

The average $L_{50}$ on Flemish Cap appears to be similar to that of Icelandic offshore waters, West Greenland 
and Barents Sea, but widely different from that of Icelandic inshore areas and Denmark Strait (Skúladóttir and Pétursson, 1999).

The proportion $L_{50} / L_{\max }$ for Flemish Cap shrimp is on average 0.80 , the same as observed in two populations in Icelandic waters and one population in Denmark Strait supporting the theory of Charnov and Skúladóttir (2000) of invariant proportion of $L_{50} / L_{\max }$ for shrimp.

Growth of shrimp on Flemish Cap was fastest in the early 1990s while temperature was still rather cold. Males changed sex a year earlier following a drastic decrease in density of female shrimp while growth was still fast. Then growth slowed down concurrent with a great increase in density of female biomass of shrimp, after the disappearance of cod on Flemish Cap in the mid 1990s. At the same time temperature started to increase a little. The rate of growth could be density dependent.

Growth of Flemish Cap shrimp is rather fast compared to shrimp from the very cold Barents Sea area and the slightly warmer inshore Iceland, but slower than that of the warm inshore waters of Sweden.

\section{Acknowledgements}

The authors would like to thank two anonymous referees for their constructive suggestions. Special thanks are due to Hrafnkell Eiriksson for critical reading of the manuscript and making the text more concise. Sigurborg Jóhannsdóttir is thanked for graphical help. The very many observers on board Icelandic shrimp vessels fishing on Flemish Cap are also thanked for their tedious work in measuring and analysing the sex stages of northern shrimp.

\section{References}

ALLEN, J.A. 1959. On the biology of Pandalus borealis Krøyer, with reference to a population off the Northumberland coast. J. Mar. Biol. Assoc. U.K., 38: 189-220.

ALLSOP, D. J., and S. A. WEST. 2003a. Constant relative age and size at sex change for sequentially hermaphroditic fish. J. Evol. Biol., 16: 921-929. doi:10.1046/j.14209101.2003.00590.x

$2003 \mathrm{~b}$. Changing sex at the same relative body size. Nature, 4: 783-784. doi:10.1038/425783a

ASCHAN, M. 2000. Spatial variability in length frequency distribution and growth of shrimp (Pandalus borealis Krøyer 1838) in the Barents Sea. J. Northw. Atl. Fish. Sci., 27: 93-105.

ATKINSON, D., and R. M. SIBLY. 1997. Why are organisms usually bigger in colder environments? Making sense of a life history puzzle. Trends Ecol. Evol., 12: 235-239.
doi:10.1016/S0169-5347(97)01058-6

BERENBOIM, B. I., A. V. DOLGOV, V. A. KORZEV, and N.A. YARAGINA. 2000. The impact of cod on the dynamics of Barents Sea shrimp (Pandalus borealis) as determined by multispecies models. J. Northw. Atl. Fish. Sci., 27: 69-75.

BERENBOIM, B. I., I. Ya. PONOMARENKO, and N. A. YARAGINA. MS 1986. On "predator-prey" relationship between cod and shrimp Pandalus borealis in the Barents Sea. ICES. C. M. Doc., 1986/G:21.

BERGSTRÖM, B. I. 1992a. Demography and sex change in pandalid shrimps. PhD thesis. Göteborg University, Faculty of Natural Sciences.

$1992 b$. Growth, growth modelling and age determination of Pandalus borealis. Mar. Ecol. Prog. Ser, 83: $167-183$.

2000. The biology of Pandalus. Adv. Mar. Biol., 38: 55-256.

BERKLEY, A. A. 1930. The post-embryonic development of the common pandalids of British Columbia. Contrib. Can. Biol. Fish., n. s. 6: 81-162.

BEVERTON, R. J. H. 1963. Maturation, growth, and mortality of clupeid and engraulid stocks in relation to fishing. Rapp. P.-v. Réun. Cons. Int. Explor. Mer., 154: 44-67.

BEVERTON, R. J. H., and S. J. HOLT. 1959. A reviev of the life-spans and mortality rates of fish in nature and their relation to growth and other physiolgical characteristics. Ciba Found. Colloq. Ageing, 5: 142-180

BRUNO, I. MS 2000. Northern shrimp (Pandalus borealis) on Flemish Cap in July 2000. NAFO SCR Doc., No. 71, Serial No. N4328, 16 p.

CASAS, J. M., J. L. DEL RIO, and D. GONZÁLEZ TRONCOSO. MS 2004. Northern shrimp (Pandalus borealis) on Flemish Cap Surveys 2003 and 2004. NAFO SCR Doc., No. 77, Serial No. N5047, 25 p.

CABANAS, J. M. MS 2003. Hydrographic conditions on Flemish Cap in July 2003. NAFO SCR Doc., No.32, Serial No. N4848, 9 p.

CHARNOV, E. L. 1982. The theory of sex allocation. Princeton University Press, Princeton, NJ. 355 p.

1993. Life history invariants. Oxford University Press, Oxford.

CHARNOV, E., and P. J. ANDERSON. 1989. Sex change and population fluctuations in pandalid shrimp. Am. Nat., 134: 824-827. doi:10.1086/285014

CHARNOV, E. L., and B.I. BERGSTRÖM. 1987. Alternative life histories in sex changing shrimp: a phenotype limited ESS. Evol. Ecol., 1: 107-111. doi:10.1007/BF02067394

CHARNOV, E., and U. SKÚLADÓTTIR. 2000. Dimensionless invariants for the optimal size (age) of sex change. Evol. Ecol. Res., 2: 1067-1071.

COLBOURNE, E. MS 2003. Oceanographic conditions on the Flemish Cap in NAFO division $3 \mathrm{M}$ during summer of 2003. NAFO SCR Doc., No. 78, Serial No. N4919, 14 p.

DEL RIO, J. L. MS 1998. Northern shrimp (Pandalus borealis) on Flemish Cap in July-August 1998. NAFO SCR Doc., No.81, Serial No. N3082, 12 p.

DEL RIO, J. M., J. M. CASAS, and D. GGONZÁLEZ TRONCOSO. MS 2003. Northern shrimp (Pandalus 
borealis) on Flemish Cap in June 2003. NAFO SCR Doc., No. 80, Serial No. N 4921, 18 p.

DEL RIO, J. M., J. M. CASAS, and T. PATROCINIO. MS 2002. Northern shrimp (Pandalus borealis) on Flemish Cap in July 2002. NAFO SCR Doc., No. 150, Serial No. $\mathrm{N}$ 4779, $21 \mathrm{p}$.

DEL RIO, J. L., and C. SAINZA. MS 1997. Northern shrimp (Pandalus borealis) stock on Flemish Cap according to 1988-1996 surveys. NAFO SCR Doc. No.87, Serial No. $\mathrm{N} 2933,23 \mathrm{p}$.

DIAZ, P. MS 2001. Northern shrimp (Pandalus borealis) on Flemish Cap in July 2001. NAFO SCR Doc., No. 172, Serial No. N 4517, 18 p.

ESCALANTE, J. L., J. VÁZQUES, and L MENA. MS 1990. Northern prawn (Pandalus borealis) stock in Flemish Cap. NAFO SCR Doc. No. 47, Serial No. N1764, 6 p.

FAO. 2000. FAO Fisheries Department, Fishery Information, Data and Statistics Unit. FISHSTAT Plus: Universal software for fishery statistical time series. Version 2.3.2000. FAO, Rome.

2006. FISHSTAT Capture Production data set 1950 2004. Release date: March 2006. http://www.fao.org.

GARABANA, D. MS 1999. Northern shrimp (Pandalus borealis) on Flemish Cap in July 1999. NAFO SCR Doc., No. 106, Serial No. N 4186, 16 p.

GIL, J., R. SANCHEZ, S. CERVINO, and D. GARABANA. 2004. Geostropic circulation and heat flux across the Flemish Cap, 1988-2000. J. Northw. Atl. Fish. Sci., 34: 63-83.

HALLIDAY, R. G., and A. T. PINHORN. 1996. North Atlantic fishery management systems: A comparison of management methods and resource trends. J. Northw. Atl. Fish. Sci., 20: 3-135.

HANSEN, H. O., and M. ASCHAN. 2000. Growth, size- and age-at-maturity of shrimp, Pandalus borealis, at Svalbard related to environmental parameters. J. Northw. Atl. Fish. Sci., 27: 83-91.

HAYNES, E. B., and R. L. WIGLEY. 1969. Biology of the northern shrimp, Pandalus borealis, in the Gulf of Maine. Trans. Am. Fish. Soc., 98: 60-76. doi:10.1577/15488659(1969)98[60:BOTNSP]2.0.CO;2

HORSTED, S. A., and E. SMIDT. 1956. The deep-sea prawn (Pandalus borealis Kr.) in Greenland waters. Medd. Dan. Fisk. Havunders., N.S. 1(11): 1-118.

KOELLER, P. A., M. COVEY, and M. KING. 2003. Is size at sex transition an indicator of growth or abundance in pandalid shrimp. Fish. Res., 65: 217-230. doi:10.1016/ j.fishres.2003.09.016

KOELLER, P., R MOHN, and R. ETTER. 2000. Density dependent sex change in northern shrimp, Pandalus borealis, on the Scotian Shelf. J. Northw. Atl. Fish. Sci., 27: 107-118.

KRISTJÁNSSON, J. MS 1996. On the biology and exploitation of shrimp in the Flemish Cap in November and December 1995. NAFO SCR Doc., No. 88, Serial No. N 2771, $10 \mathrm{p}$.

MS 2001. Changes in population structure of the shrimp (Pandalus borealis) stock on Flemish Cap 19952000. NAFO SCR Doc., No. 171, Serial No. N4516, 5 p.
LILLY, G. R., D. G. PARSONS, and D. W. KULKA. 2000. Was the increase in shrimp biomass on the Northeast Newfoundland shelf a consequence of a release in predation pressure from cod? J. Northw. Atl. Fish. Sci., 27: 45-61.

MCCRARY, J.A. 1971. Sternal spines as a characteristic for differentiating between females of some Pandalidae. $J$. Fish. Res. Board Can., 28: 98-100.

MACDONALD, P. D. M., and T. J. PITCHER. 1979. Age groups from size-frequency data: A versatile and efficient method of analysing distribution mixtures. J. Fish. Res. Board Can., 36: 987-1011.

MENA, I. MS 1991. Northern prawn (Pandalus borealis) length distribution and fecundity in Flemish Cap. NAFO SCR Doc., No. 29, Serial No. N1909, 7 p.

MITANI, F. 1970. A comparative study on growth patterns of marine fishes. Bull. Jap. Soc. scient. Fish., 36: 258-265.

NAFO. 2005. Scientific Council Reports 2004. Northwest Atlantic Fisheries Organization, Dartmouth, NS, Canada. $298 \mathrm{p}$.

NICOLAJSEN, A. MS 1998. Biomass estimate, length and age distribution of the northern shrimp (Pandalus borealis) stock on Flemish Cap (NAFO division 3M) in July 1998 and Faroese catches in 1997 and 1998. NAFO SCR Doc. , No. 83, Serial No. N3084, 19 p.

MS 1999. Biomass estimate, growth, length and age distribution of the northern shrimp (Pandalus borealis) stock on Flemish Cap (NAFO division 3M) in July 1999 and Faroes catches 1996-1999. NAFO SCR Doc., No. 114, Serial No. N4195, 18 p.

MS 2000. Biomass estimate, growth, length and age distribution of the northern shrimp (Pandalus borealis) stock on Flemish Cap (NAFO division 3M) in June 2000. NAFO SCR Doc., No. 83, Serial No. N4340, 17 p.

MS 2001. Biomass estimate, growth, length and age distribution of the northern shrimp (Pandalus borealis) stock on Flemish Cap (NAFO division 3M) in June 2001. NAFO SCR Doc., No. 188, Serial No. N4578, 20 p.

MS 2002. Biomass estimate, growth, length and age distribution of the northern shrimp (Pandalus borealis) stock on Flemish Cap (NAFO division 3M) in June 2002. NAFO SCR Doc., No. 156, Serial No. N4785, 20 p.

MS 2003. Biomass estimate, growth, length and age distribution of the northern shrimp (Pandalus borealis) stock on Flemish Cap (NAFO division 3M) in June 2003. NAFO SCR Doc., No. 87, Serial No. N4929, 12 p.

NICOLAJSEN, A., and S. H. BRYNJÓLFSSON. MS 2003. Young northern shrimp (Pandalus borealis) index for Flemish Cap (NAFO Division 3M) 2003. NAFO SCR Doc., No. 66, Serial No. N4893, 4 p.

PARKER, G. A. 1982. Phenotype-limited evolutionary stable strategies. In: Current Problems in Sociobiology. Kings College Sociobiology Group (eds). Cambridge University Press, New York. p. 173-201.

PARSONS, D. G. MS 1996. Report of the ad hoc working group on shrimp (Pandalus borealis) Division 3M. NAFO SCS. Doc., No. 19, Serial No. N2817, 7 p.

PARSONS. D. G., E. B. COLBOURNE, G. R. LILLY, and D. W. KULKA. 1998. Northern shrimp (Pandalus borealis) 
on Flemish Cap (NAFO Division 3M) - oceanography, fishery and biology. J. Northw. Atl. Fish. Sci., 24: 1-26.

PARSONS, D. G., and P. J. VEITCH. MS 1997. The Canadian fishery for northern shrimp (Pandalus borealis) on Flemish Cap (NAFO Division 3M), 1993-1997. NAFO SCR Doc., No. 83, Serial No. N2929, 11 p.

PAULY, D. 1981. The relationship between gill surface area and growth performance in fish: a generalization of von Bertalanffy's theory of growth. Meeresforsch./Rep.mar. Res., 28: 251-282.

1984. A mechanism for the juvenile to adult transition in fishes. J. Cons. int. Explor. Mer, 41: 280-284.

2000. The maturity table. In: FishBase 2000: concepts, design and data sources. Froese, R. and D. Pauly (eds.). www.fishbase.org. 344 p.

PEARL, R., and L. J. REED. 1920. On the rate of growth of the population of the U.S. since 1790 and its mathematical representation. Proc. Nat. Acad. Sci., 6: 275-288. doi:10.1073/pnas.6.6.275

RASMUSSEN, B. 1953. On the geographical variation in growth and sexual development of the deep sea prawn (Pandalus borealis Kr.). Norweg. Fish. and Mar. Invest. Rep., 10 (3): 1-160.

SABORIDO-REY, F., and A. VÁZQUES. MS 2003. Results from bottom trawl survey on Flemish Cap of July 2002. NAFO SCR Doc., No. 42, Serial No. N4860, 41 p.

SAINZA, C. MS 1993. Northern shrimp (Pandalus borealis) stock on Flemish Cap in June-July 1993. NAFO SCR Doc., No. 104, Serial No. N3281, 8 p.

SHUMWAY, S. E., H. C. PERKINS, D. F. SCHICK, and A. P. STICKNEY. 1985. Synopsis of biological data on the pink shrimp Pandalus borealis Krøyer, 1838. NOAA Technical Report, NMFS, 30: 57 p.

SKÚLADÓTTIR, U. 1981. The deviation method. A simple method for detecting year-classes of a population of Pandalus borealis from length distributions. In: Proc. Int. Pandalid Shrimp Symp., T. Frady (ed.). Kodiak, Alaska, 13-15 Feb 1979. p. 283-306.

MS 1997. The Icelandic shrimp fishery (Pandalus borealis Kr.) on Flemish Cap in 1993-1997 NAFO SCR Doc., No. 85, Serial No. N2931, 30 p.

1998. Size at sexual maturity of female northern shrimp (Pandalus borealis Krøyer) in the Denmark Strait 1985-93 and a comparison with the nearest Icelandic shrimp populations. J. Northw. Atl. Fish. Sci., 24: 27-37.

MS 2003a. An update of the Icelandic shrimp fishery (Pandalus borealis Kr.) on Flemish Cap in 1993-2003. NAFO SCR Doc., No.83, Serial No. N4925, 20 p.

MS 2003b. An update of the assessment of the international fishery for shrimp (Pandalus borealis) in Division 3M (Flemish Cap), 1993-2003. NAFO SCR Doc., No. 91, Serial No. N4933, 14 p.

MS 2004. An update of the Icelandic shrimp fishery (Pandalus borealis Kr.) on Flemish Cap in 1993-2004. NAFO SCR Doc., No.84, Serial No. N5054, 20 p.

SKÚLADÓTTIR, U., and P. DIAZ. MS 2001. Age Assessment of northern shrimp (Pandalus borealis) in EU surveys on
Flemish Cap in 1988-2001. NAFO SCR Doc., No. 189, Serial No. N4579, 8 p.

SKÚLADÓTTIR, U., and Á. GUDMUNDSDÓTTIR. MS 2004. An update of the international fishery for shrimp (Pandalus borealis) in division 3M (Flemish Cap), 1993-2004 in November 2004. NAFO SCR Doc., No. 89, Serial No. N5059, 20 p.

SKÚLADÓTTIR, U., and A. NICOLAJSEN. MS 2002. The impact of closure of the shallow water area of Flemish Cap (Division 3M) on young shrimp (Pandalus borealis) in two periods of the year. NAFO SCR Doc., No. 77, Serial No. N4691, 17 p.

SKÚLADÓTTIR, U., J. PÁLSSON, G. S. BRAGASON, and V. HELGASON. MS 1989. The stock size of Pandalus borealis in Isafjardardjup estimated by VPA and area swept. NAFO SCR Doc., No. 96, Serial No. N1698, 23 p.

SKÚLADÓTTIR, U., J. PÁLSSON, G. S. BRAGASON, and S. BRYNJÓLFSSON. MS 1991. The variation in size and age at change of sex, maximum length and length of ovigerous periods of the shrimp Pandalus borealis, at different temperatures in Icelandic waters. ICES C. M. Doc., 1991/K:5, 15 p.

SKÚLADÓTTIR, U., and G. PÉTURSSON. 1999. Defining population of northern shrimp, Pandalus borealis (Krøyer 1838), in Icelandic waters using maximum length and maturity ogive of females. Rid Fiskideildar/J. Mar. Res. Inst., 16: $247-262$.

SKÚLADÓTTIR, U., and G. PÉTURSSON. MS 2005. Assessment of the international fishery for shrimp (Pandalus borealis) in division 3M (Flemish Cap), 1993-2005. NAFO SCR Doc., No. 89, Serial No. N5194, 21 p.

SKÚLADÓTTIR, U., G. PÉTURSSON, and S. BRYNJÓLFSSON. MS 2004. The biology of northern shrimp (Pandalus borealis, Krøyer 1838) on Flemish Cap. NAFO SCR Doc., No. 64, Serial No. N5025, 10p.

SKÚLADÓTTIR, U., and J. SIGURJÓNSSON. 2004. Pandalus stocks in Icelandic waters: biology, exploitation and management. In: Management strategies for commercial marine species in northern ecosystem. Bjordal, Gjosæter and Mehl (eds.). Proceedings of the Norwegian-Russian Symp. IMR/PINRO 1 2004. Bergen, Norway, 27-29 Aug 2003. p. 104-116.

STEFÁNSSON, G., U. SKÚLADÓTTIR, and B. Æ. STEINARSSON. 1998. Aspects of the ecology of a boral system. ICES J. Mar. Sci., 55: 859-862. doi:10.1006/ jmsc. 1998.0359

SUND, O. 1930. The renewal of fish population studied by means of measurement of commercial catches. Example: the arcto Norwegian cod stock. Rapp. P.-v. Réun. Cons. Int. Explor. Mer., 65: 10-17.

VÁZQUES, A. MS 1989. Results from bottom-trawl survey of Flemish Cap in July 1988. NAFO SCR Doc., No 60, Serial No. N1640, 15 p.

WIELAND, K. 2004. Length at sex transition in northern shrimp (Pandalus borealis) off Greenland in relation to changes in temperature and stock size. Fish. Res., 69: 49-56. doi:10.1016/j.fishres.2004.04.003 